\title{
Melt-Dilute Spent Nuclear Fuel Form Criticality Summary Report
}

by

D. W. Vinson

Westinghouse Savannah River Company

Savannah River Site

Aiken, South Carolina 29808

A. W. Serkiz

This paper was prepared in connection with work done under the above contract number with the U. S. Department of Energy. By acceptance of this paper, the publisher and/or recipient acknowledges the U. S. Government's right to retain a nonexclusive, royalty-free license in and to any copyright covering this paper, along with the right to reproduce and to authorize others to reproduce all or part of the copyrighted paper. 
WSRC-TR-2001-00421

Keywords: Criticality, Shielding, Melt-Dilute, Spent Nuclear Fuel, Yucca Mountain

\section{Melt-Dilute Spent Nuclear Fuel Form Criticality Summary Report}

Savannah River Technology Center

Strategic Materials Technology Department

Materials Technology Section

Publication Date: September 2001

\section{Westinghouse Savannah River Company \\ Savannah River Site Aiken, SC 29808}

This document was prepared in connection with work done under Contract No. DE-AC09-96SR18500 with the U. S. Department of Energy 
This document was prepared in conjunction with work accomplished under Contract No. DE-AC09-96SR18500 with the U. S. Department of Energy.

\section{DISCLAIMER}

This report was prepared as an account of work sponsored by an agency of the United States Government. Neither the United States Government nor any agency thereof, nor any of their employees, makes any warranty, express or implied, or assumes any legal liability or responsibility for the accuracy, completeness, or usefulness of any information, apparatus, product or process disclosed, or represents that its use would not infringe privately owned rights. Reference herein to any specific commercial product, process or service by trade name, trademark, manufacturer, or otherwise does not necessarily constitute or imply its endorsement, recommendation, or favoring by the United States Government or any agency thereof. The views and opinions of authors expressed herein do not necessarily state or reflect those of the United States Government or any agency thereof.

This report has been reproduced directly from the best available copy.

Available for sale to the public, in paper, from: U.S. Department of Commerce, National Technical Information Service, 5285 Port Royal Road, Springfield, VA 22161, phone: (800) 553-6847, fax: (703) 605-6900

email: orders@ ntis.fedworld.gov

online ordering: http://www.ntis.gov/support/index.html

Available electronically at http://www.osti.gov/bridge

Available for a processing fee to U.S. Department of Energy and its contractors, in paper, from: U.S. Department of Energy, Office of Scientific and Technical Information, P.O. Box 62, Oak Ridge, TN 37831-0062,

phone: (865)576-8401,

fax: (865)576-5728

email: $\underline{\text { reports@ adonis.osti.gov }}$ 
DOCUMENT: WSRC-TR-2001-00421

TITLE: $\quad$ Melt-Dilute Spent Nuclear Fuel Form Criticality Summary Report

TASK: $\quad$ SRT-MTS-2000-2035, Rev. 0, Subtask 1.1

\section{APPROVALS}

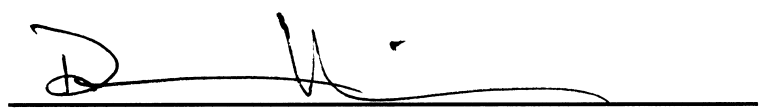

D. W. Vinson, Author

SRTC-Materials Applications \& Process Technology Group MATERIALS TECHNOLOGY SECTION
Date: $\quad q / 2 / 01$
AW Serkiz by KZ tidela
A. W. Serkiz, Author
Date: $9 / 12 / 01$

SCUREF Scientist, Materials Applications \& Process Technology Group

MATERIALS TECHNOLOGY SECTION

T. M. Adams, Technical Review

SRTC-Materials Applications \& Process Technology Group

MATERIALS TECHNOLOGY SECTION

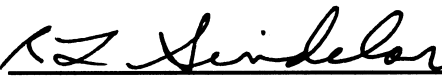

R. L. Sindelar, Manager

SRTC-Materials Applications \& Process Technology Group

MATERIALS TECHNOLOGY SECTION

N. C. Iyer, Mapager

SRTC-MATERIALS TECHNOLOGY SECTION

Bur R Hen

B. R. Hess, Manager

NMMD-TSF/Alternate Technologies

SFP ENGINEERING
Date: $9 / 12 / 01$

Date: $9 / 12 / 01$

Date: $9 / 12-101$

Date: $9 / 12 / 01$ 


\section{Table of Contents}

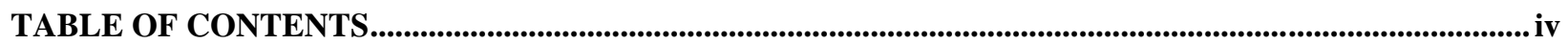

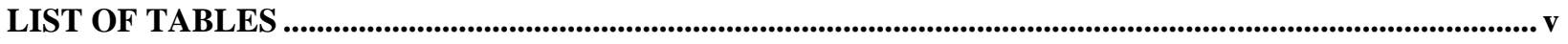

LIST OF FIGURES ........................................................................................................................................................................ vi

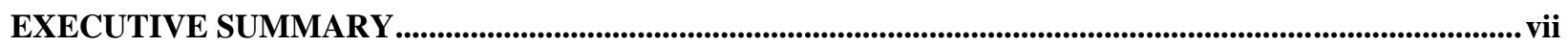

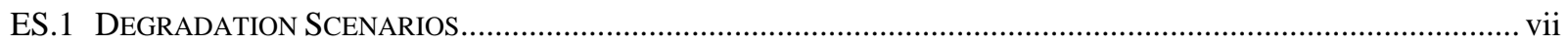

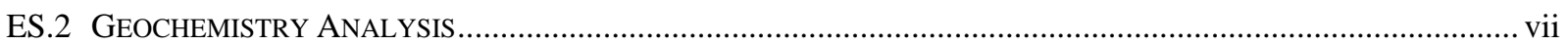

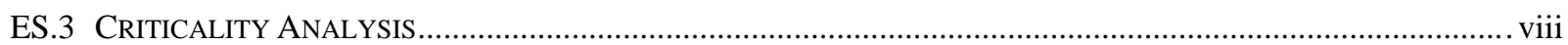

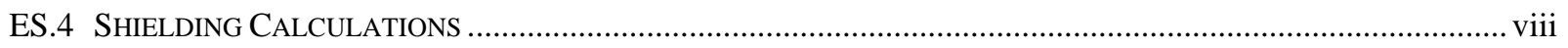

ES.5 CONCLUSIONS ....................................................................................................................... vii

1.0 INTRODUCTION AND BACKGROUND …............................................................................................... 1

2.0 CODISPOSAL WASTE PACKAGE DEGRADATION ANALYSIS ..........................................................2

2.1 SySTEMATIC INVESTIGATION OF DEGRADATION SCENARIOS AND CONFIGURATIONS .................................... 2

2.2 APPLICATION OF STANDARD SCENARIOS TO MELT AND DILUTE INGOTS .................................................... 2

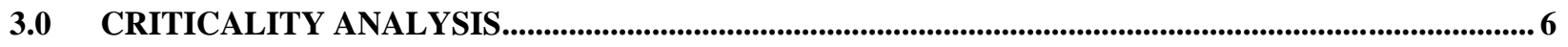

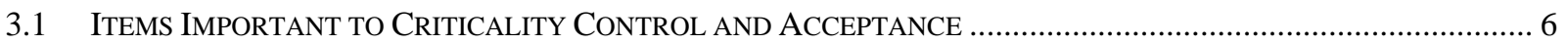

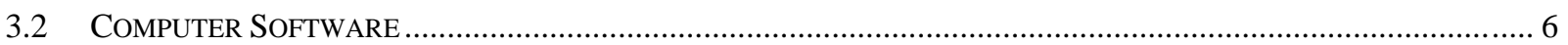

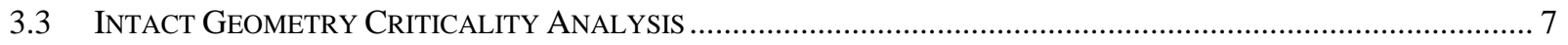

3.4 WASTE Form DEGRADES BEFORE THE INTERNAL COMPONENTS OF THE WASTE PACKAGE ......................... 10

3.5 ALl COMPONENTS INTERNAL TO WASTE PACKAGE DEGRADED ……........................................................... 12

3.5.1 Stratified Layers of $\mathrm{UO}_{2}$ and Post-breach Clay Without Neutron Absorber ...................................... 14

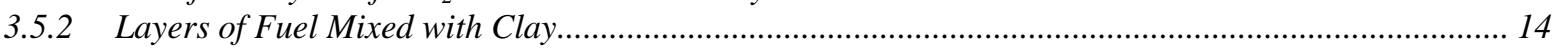

3.6 INTERNAL COMPONENTS OF THE WASTE PACKAGE DEGRADED (OUTSIDE INTACT DOE SNF

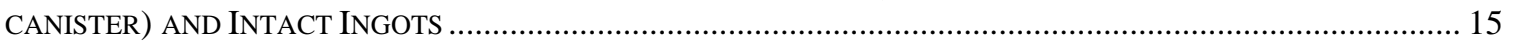

3.6.1 Wet Intact Ingots with Full or Partial Gd ................................................................................. 17

3.6.2 Intact Melt and Dilute Ingots in the Waste Package ..................................................................... 19

3.6.3 Degraded Melt and Dilute Ingots ................................................................................................. 19

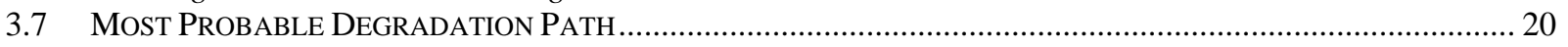

3.8 INTACT AND DEGRADED COMPONENT CRITICALITY CONCLUSIONS ............................................................ 22

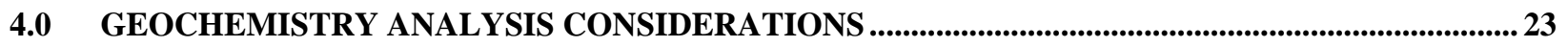

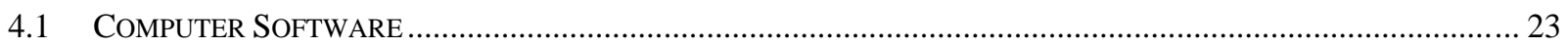

4.2 BASIC DESIGN APPROACH FOR GEOCHEMISTRY ANALYSIS......................................................... 23

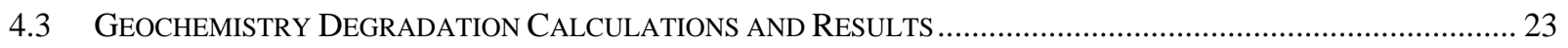

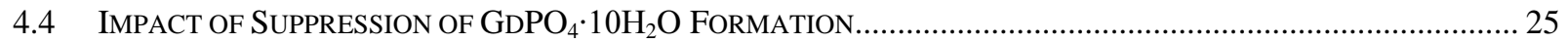

4.5 SUPPRESSING THE FORMATION OF IRON MINERALS TO CONTROL IONIC STRENGTH ................................... 26

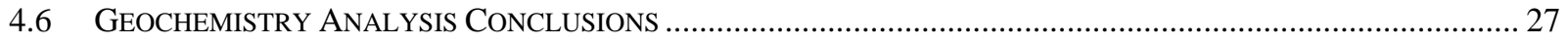

5.0 SHIELDING ANALYSIS ..........................................................................................................................................28

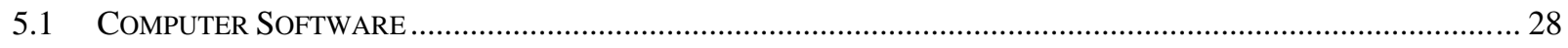

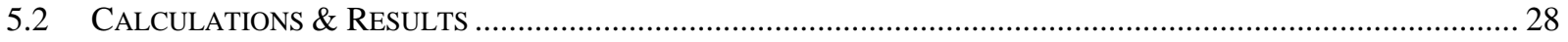

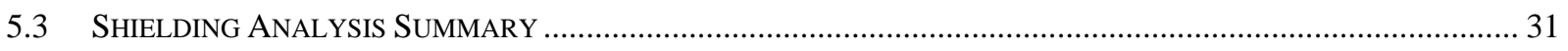

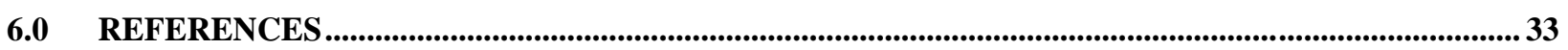


WSRC-TR-2001-00421

Page $v$ of $x$

September 2001

\section{List of Tables}

Table ES.1 Criticality Evaluation Summary for Degraded Configurations ...........................................................

Table 3.1 Criticality Evaluation Summary for Degraded Configurations ............................................................... 8

Table 3.2 Results for Intact Mode Configurations...................................................................................... 9

Table 3.3 Results for Degraded Fuel in Intact DOE SNF Canister and Waste Package ................................... 11

Table 3.4 Results for Degraded Fuel in Intact DOE SNF Canister and Waste Package ................................... 12

Table 3.5 Results for Stratified $\mathrm{UO}_{2}$ and Clay Inside Waste Package .............................................................. 14

Table $3.6 \quad$ Layers of Fuel Mixed with Clay .................................................................................................. 15

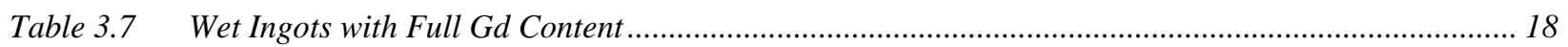

Table $3.8 \quad$ Wet Ingots with Partial Gd Content ……................................................................................. 18

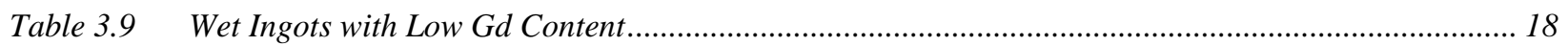

Table 3.10 Results for Array of Ingots Inside Waste Package ............................................................................. 19

Table 3.11 Degraded Ingots in Intact DOE SNF Canister with Degraded Waste Package Internals..................... 19

Table 3.12 Properties of Materials in Melt and Dilute Codisposal Waste Package ............................................ 21

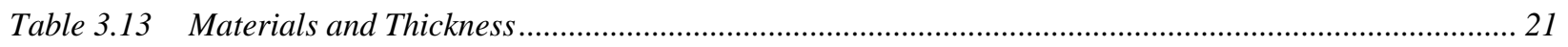

Table 4.1 Cases Varying the Sequence of Degradation...................................................................................... 24

Table 4.2 Cases Suppressing $\mathrm{GdPO}_{4} \cdot 10 \mathrm{H}_{2} \mathrm{O}$ Formation .............................................................................. 25

Table 4.3 Cases Suppressing the Formation of Various Minerals ................................................................. 27

Table 5.1 Dose Rates Averaged over Axial and Radial Segments of the WP Outer-Radial and Axial Surfaces ${ }^{5}$

Table 5.2 Dose Rates Averaged Over Angular Segments of the WP Outer-Radial Surface................................ 31 


\section{List of Figures}

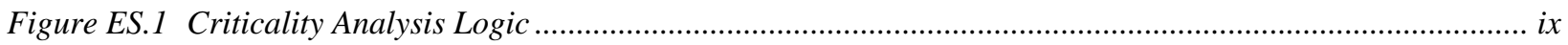

Figure 2.1 Conceptual Sketch of WP for Degradation Scenario IP-1 ….......................................................... 3

Figure 2.2 Conceptual Sketch of WP for Degradation Scenario IP-2 ……................................................... 4

Figure 2.3 Conceptual Sketch of WP for Degradation Scenario IP-3 .......................................................... 5

Figure 3.1 Cross-section View of the 5-DHLW/DOE Waste Package in an as-Loaded (intact)

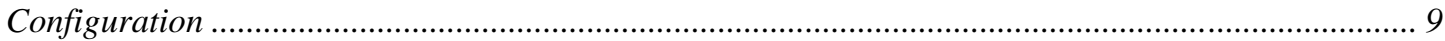

Figure 3.2 Cross-section View of Degraded Fuel in an Intact Waste Package ................................................. 10

Figure 3.3 Cross-section View of WP with All Components Degraded ........................................................... 13

Figure 3.4 Cross-section View of Simulated Tilt of Waste Package ................................................................ 14

Figure 3.5 Cross-section Views of Intact DOE SNF Canister Degraded Internal Waste Package

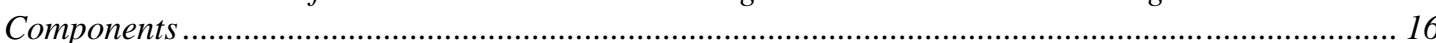

Figure 3.6 Cross-section View of Simulated Tilt of Intact DOE SNF Canister with Degraded Fuel and Degraded Internal Waste Package Components .............................................................................. 17

Figure 3.7 Array of 9 Ingots Inside the Waste Package Surrounded with Water.................................................. 17

Figure 5.2 Surfaces and Segments (axial and radial) Used for Dose Rate Calculations........................................ 30

Figure 5.3 Angular Segments of the WP Outer Radial Surface Used in Dose Rate Calculations ......................... 30 


\section{Executive Summary}

Criticality analysis of the proposed Melt-Dilute (MD) form of aluminum-based spent nuclear fuel (SNF), under geologic repository conditions, was performed following the methodology, documented in the Disposal Criticality Analysis Methodology Topical Report. This methodology evaluates the potential for nuclear criticality as determined by the composition of the waste and its geometry, namely waste form configuration, including presence of moderator, reflecting structural material, and neutron absorbers. The initial emplaced configuration of the SNF form is a dry package placed in a mined repository passageway. Criticality calculations show that even with waste package failure, followed by degradation of material within the waste package and potential loss of neutron absorber materials, sub-critical conditions can be maintained.

Detailed analyses and findings reported in the Bechtel-SAIC Report, TDR-EDC-NU-000006 Rev 00, "Evaluation of Codisposal Viability for Melt and Dilute DOE-Owned Fuel," July 2001 were used to construct this summary report and should be referred to for additional information as needed. The results show that the proposed melt-dilute form containing gadolinium and/or hafnium as neutron absorbers will maintain subcriticality and that the interim repository subcriticality criterion $\mathrm{k}_{\text {eff }}+2 \sigma \leq 0.93$ can be met. ${ }^{a}$

The 5-DHLW/DOE SNF waste package for repository disposal is comprised of one 18-in.-outer diameter DOE standardized SNF canister containing the MD ingots, surrounded by five defense high-level radioactive waste (DHLW) glass canisters as shown in Figure ES-1. This intact waste package design is subjected to degradation scenarios comprised of a combination of features, events, and processes (FEPs) that can result in degraded configurations to be evaluated for criticality. The assessment of the criticality potential of the waste package involves (i) degradation scenarios analyses; (ii) geochemistry analysis; and (iii) criticality analysis. These are briefly summarized herein.

\section{ES.1 Degradation Scenarios}

Three master degradation scenarios, shown as IP-1, IP-2 and IP-3 in Figure ES-1, were used for evaluation of the physical and chemical interactions (e.g. ground water flow, corrosion, and precipitation) that can occur between the emplaced material and site surroundings and development of criticality analysis models.

The master scenarios (IP-1, IP-2, and IP-3) were based on liquid accumulating in the waste package coupled with scenarios assuming the MD ingots degrading before, concurrently and after, and degradation of other internal components (OICs). The development and selection of these waste package degraded configurations is discussed in Section 2.0.

\section{ES.2 Geochemistry Analysis}

A principal objective of the geochemistry analysis was to estimate the chemical composition of the degradation products remaining in a waste package containing MD ingots and high-level waste glass. Two compositions were considered in the analysis. The first composition was $13.2 \pm 5 \mathrm{wt} \%$ uranium, enriched at less than $20 \%{ }^{235} \mathrm{U}$, and $0.5 \mathrm{wt} \%$ gadolinium metal, with the balance being aluminum. The

\footnotetext{
a The criterion of $k_{\text {eff }}+2 \sigma \leq 0.93$ has been used in calculations performed in preparation of the subject document. This value has been derived as unity (critical) less the sum of a five percent margin (10 CFR 60.131(h)) and estimates for calculational bias, and the uncertainty of the experiments used to validate the method of calculation. That is, $\mathrm{k}_{\text {eff }}+$ uncertainty + bias + margin $=1$; where uncertainty $=2 \sigma$, bias $=0.02$, and margin $=0.05$. The estimates of bias and bias-uncertainty are taken as the worst-case values calculated from the MCNP simulations of the validation experiments. These estimates will be confirmed at a later time.
} 
second composition is the same as the first except that $2.5 \mathrm{wt} \%$ of hafnium is included with the balance being aluminum. Although most of the geochemistry analysis cases showed that more than $80 \%$ of the initial Gd content will remain in the waste package under postulated conditions, there were several computational scenarios selected which degraded the MD ingots first and then the DHLW glass while suppressing (a calculational suppression) the formation of compounds such as $\mathrm{GdPO}_{4} \cdot 10 \mathrm{H}_{2} \mathrm{O}$. Such calculations show significant loss of $\mathrm{Gd}$, including total depletion of gadolinium while retaining $\mathrm{U}$.

The formation of $\mathrm{GdPO}_{4} \cdot 10 \mathrm{H}_{2} \mathrm{O}$ is expected and will be an asset in retaining $\mathrm{Gd}$ in sufficient quantity to avoid criticality as shown by these analyses. Experimental verification of the formation of $\mathrm{GdPO}_{4} \cdot 10 \mathrm{H}_{2} \mathrm{O}$ in model systems is being pursued in laboratory tests at SRTC.

\section{ES.3 Criticality Analysis}

Three-dimensional Monte Carlo criticality calculations were performed for all anticipated intact- and degraded-mode configurations and the results are shown in Table ES-1. Calculations show that the requirement of $k_{\text {eff }}+2 \sigma$ values less than or equal to the interim critical limit of 0.93 is satisfied for the MD codisposal package if at least $7.5 \%$ of the original Gd loading remains mixed with the fissile material. Hafnium, used in the alternate MD ingot composition, is predicted to remain in the DOE SNF canister or waste package in the limited number of conditions analyzed, thus preventing a critical condition even if all Gd is removed from the system.

\section{ES.4 Shielding Calculations}

Three-dimensional shielding calculations were performed using a Monte Carlo particle transport code, MCNP, Version 4B2LV to calculate average dose rates at the external surfaces of the waste package. The design criteria specify that a maximum dose rate on all external surfaces not exceed $1,450 \mathrm{rem} / \mathrm{hr}$. A maximum surface dose rate of approximately $200 \mathrm{rem} / \mathrm{hr}$ was calculated. This level is well within the prescribed limit. The purpose of this $1,450 \mathrm{rem} / \mathrm{hr}$ limit is to limit the personnel exposure at the repository handling facility. In addition, it has been shown that the radiation generated by the MD-SNF form will not lead to irradiation enhanced waste package degradation under repository disposal conditions.

\section{ES.5 Conclusions}

A criticality and shielding analysis of the 5-DHLW/DOE waste package has been completed. The results summarized above show that subcritical conditions can be achieved and maintained and that the waste package surface radiation level is well within the specified limit.

This report summarizes criticality and shielding findings pertinent to the 5-DHLW/DOE Melt Dilute short waste package and therefore completes the work requirements contained in Subtask 1.1, Appendix A of SRT-MTS-2000-2035, Rev. 0, 2/1/2001. 


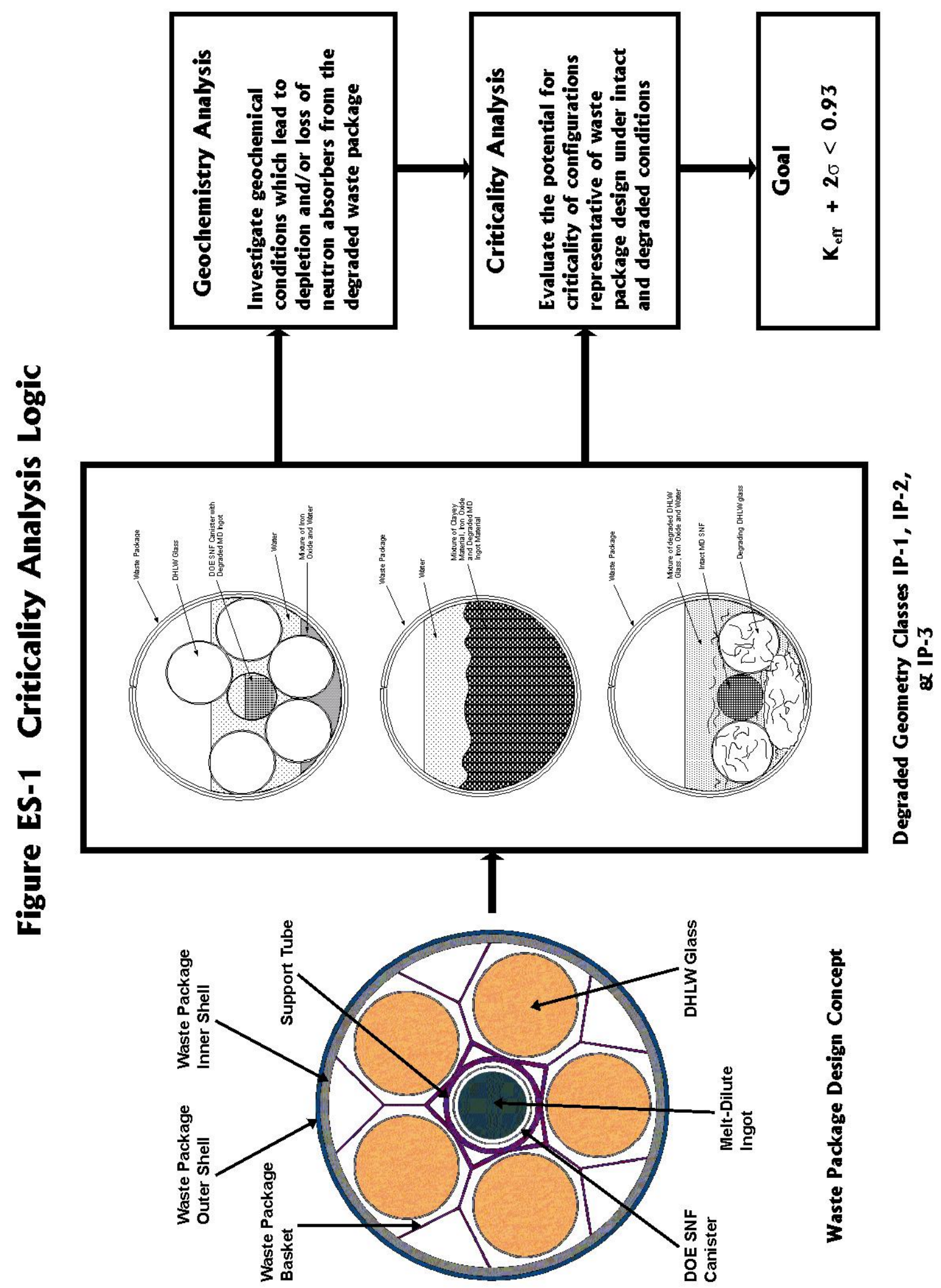




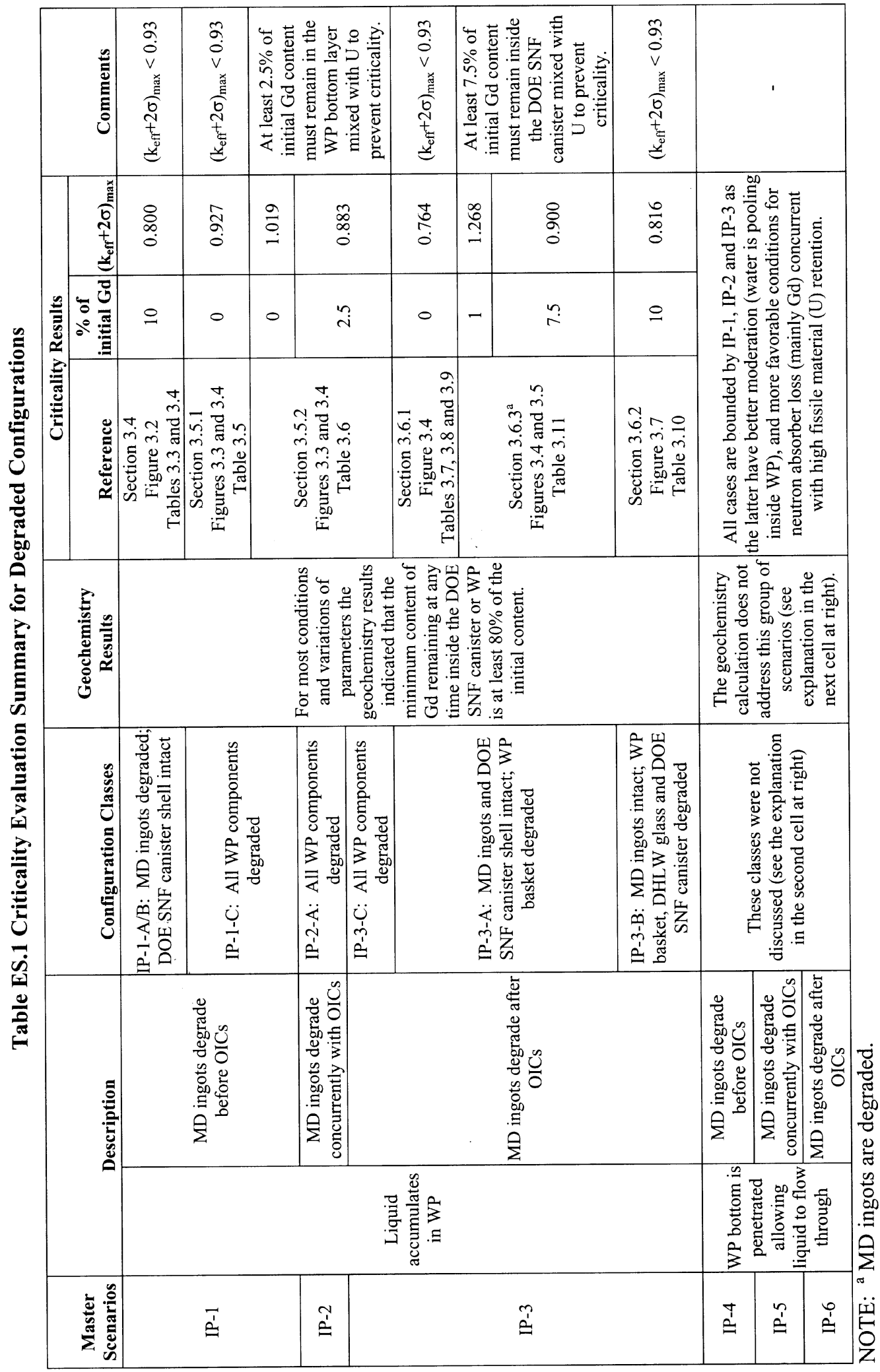




\subsection{INTRODUCTION AND BACKGROUND}

There are more than 250 forms of U.S. Department of Energy (DOE)-owned spent nuclear fuels (SNF). Due to the variety of the spent nuclear fuel, the National Spent Nuclear Fuel Program has designated nine representative fuel groups for disposal criticality analyses based on fuel matrix, primary fissile isotope, and enrichment. The Melt and Dilute (MD) fuel form has been designated as the representative fuel for the high-enriched U-Al fuel group. ${ }^{1}$ Demonstration that other fuels in this group are bounded by the MD fuel analysis remains to be done before acceptance of these fuel forms. The information for the representative fuel type is provided in the Reference 2. The results of the analyses performed by using the information from this reviewed data report will be used to develop waste acceptance criteria which must be met by all fuel forms within the high-enriched U-Al fuel group. The items that are important to criticality control are identified based on analysis needs and result sensitivities. Prior to acceptance of the fuel from the high-enriched U-Al fuel group for disposal, the important items of the fuel types that are being considered for disposal under the high-enriched U-Al fuel group must be demonstrated to satisfy the conditions set in Section 8.6 of Reference 3, "Items Important to Criticality".

The MD technology development program is focused on the development and implementation of a treatment technology for diluting high-enriched U-Al SNF to low-enriched U levels ( $<20 \mathrm{wt} \%)$ and qualifying this low-enriched U-Al SNF form, MD DOE SNF, for geologic repository disposal. The following assumptions for the MD form were used as design information to use in the criticality analyses.

The MD ingots are homogeneous and monolithic cylinders that will range in height from 15 to 30 in. ( $381 \mathrm{~mm}$ to $762 \mathrm{~mm}$ ) and will likely be contained in a plain carbon steel crucible liner. The liner will have the maximum outer diameter of $16.5 \mathrm{in} .(419.1 \mathrm{~mm})$. The composition is $13.2 \pm 5 \mathrm{wt} \%$ uranium, enriched at less than $20 \%{ }^{235} \mathrm{U}$ and $0.5 \mathrm{wt} \%$ gadolinium metal, with the balance of the ingot being aluminum. A second composition is also considered, which is identical to the first for uranium and gadolinium, except that in this case $2.5 \mathrm{wt} \%$ of the ingot is hafnium, with the balance of the ingot being aluminum.

The 5-DHLW/DOE SNF waste package is comprised of one 18-in.-outer diameter DOE standardized SNF canister containing the MD ingots, surrounded by five defense high-level radioactive waste (DHLW) glass canisters as shown in Figure 3.1. These are emplaced within the waste package structure consisting of two concentric cylindrical shells. The outer shell is made of a corrosion resistant nickel-based alloy (Alloy 22) and the inner shell is composed of stainless steel $316 \mathrm{NG}$ (nuclear grade). The waste package design has three lids at the one end of the waste package (one for the inner shell and two for the outer shell) and two lids at the other end of the waste package (one for each shell). The DOE SNF canister containing three to six MD ingots is placed in a carbon steel support tube that becomes the center of this waste package.

Criticality analyses have been performed by the DOE-Office of Civilian Radioactive Waste Management (RW) according to the Disposal Criticality Analysis Methodology Topical Report. ${ }^{4}$ This report had been submitted to the U.S. Nuclear Regulatory Commission as part of the pre-license exchange of information. The methodology includes analyzing the geochemical and physical processes that can breach the waste package and degrade the waste forms as well as the intact and degraded component criticality analyses. Addenda to the topical report will be required to establish the critical limit for the DOE SNF types once sufficient critical benchmarks are identified and run.

Shielding calculations were performed according to Reference 5, Dose Rate Calculation for the Codisposal Waste Package of HLW and the Melt Dilute Al-SNF. The detailed analyses and findings are reported in Reference 3 and were used to construct the summaries that follow. 


\subsection{CODISPOSAL WASTE PACKAGE DEGRADATION ANALYSIS}

\subsection{Systematic Investigation of Degradation Scenarios and Configurations}

Degradation scenarios comprise a combination of features, events, and processes that result in degraded configurations to be evaluated for criticality. A configuration is defined by a set of parameters characterizing the amount and physical arrangement, at a specific location, of the materials that can significantly affect criticality (e.g., fissile materials, neutron absorbing materials, reflecting materials, and moderators). The variety of possible configurations is best understood by grouping them into classes. A configuration class is a set of similar configurations whose composition and geometry is defined by specific parameters that distinguish one class from another. Within a configuration class, the values of configuration parameters may vary over a given range.

A master scenario list and set of configuration classes relating to internal criticality is given in the Disposal Criticality Analysis Methodology Topical Report. ${ }^{4}$ This list was developed by a process that involved workshops and peer review. The comprehensive evaluation of disposal criticality for any waste form must include variations of the standard scenarios and configurations to ensure that no credible degradation scenario is neglected. All of the scenarios that can lead to criticality begin with the breaching of the waste package, followed by entry of water, which eventually leads to degradation of the spent nuclear fuel and/or other internal components of the waste package.

\subsection{Application of Standard Scenarios to Melt and Dilute Ingots}

The MD SNF has the following characteristics in terms of geometrical arrangement inside the codisposal WP and the distribution of the neutron absorber:

1. There is no internal structure inside the DOE SNF canister. The ingots fill most of the space inside the DOE SNF canister and thus do not need a support structure, but a carbon steel crucible liner may encase the MD ingot. This implies that configurations following from degradation of DOE SNF canister basket structure are not valid for the MD SNF disposal.

2. Neutron absorber and SNF are merged metallurgically in the ingot. Physical separation of neutron absorber is not possible, as is degradation of the neutron absorber while fuel stays intact. This means that separation mechanisms such as differential settling of solid particles of different densities (see section 6.4.2 of Reference 6) are not applicable for the MD SNF.

Based on these characteristics the application of scenarios is as follows:

IP-1: The configurations resulting from IP-1 scenario (see Figure 2.1) involve the MD ingots degrading before other internal components and depends on the degradation rates of the various materials that make up the OICs as compared to the degradation rate of the ingots. The degradation rates show that the ingot high rate is $4.8 \times 10^{-12} \mathrm{~mol} \cdot \mathrm{cm}^{-2} \cdot \mathrm{s}^{-1}$ while the low rate of the SS components is $2.5 \times 10^{-14} \mathrm{~mol} \cdot \mathrm{cm}^{-2} \cdot \mathrm{s}^{-1}$. The carbon steel has a degradation rate of $1.8 \times 10^{-11} \mathrm{~mol} \cdot \mathrm{cm}^{-2} \cdot \mathrm{s}^{-1}$. Therefore, the degradation of the carbon steel basket and the ingot, with the stainless steel and DHLW glass components intact, is possible. Since there is no basket structure in the DOE SNF canister associated with the MD ingots, configuration variations within the DOE SNF canister are limited. Possible variations are configurations with partial or total degradations of the components outside the DOE SNF canister. The DOE SNF canister falls to the bottom of the WP. Near the end of this sequence, layers of degradation products in the WP might result surrounding a partially degraded DOE SNF canister shell. 
IP-2: In the configurations resulting from IP-2 scenario (see Figure 2.2), the SNF may degrade simultaneously with the other components in the WP if the environmental conditions favor glass degradation rates that are comparable to ingot and steel degradation rates. Figure 5-4 is an example. In this scenario the gradual degradation of the various constituents could result in a configuration where higher density material collects at the bottom of the waste package while lower density material stays on top. The potential for criticality could be significant if the neutron absorber $\left(\mathrm{Gd}\right.$ as $\mathrm{GdPO}_{4}-$ the most likely mineral to form enters into solution and is flushed out of the WP while the fissile material is in a geometry favorable to criticality. Because the Gd is integral to the MD ingots, this would require complete degradation of the ingots. Gd loss also depends on the fraction of $\mathrm{GdPO}_{4}$ formed as a result of the geochemistry analysis.

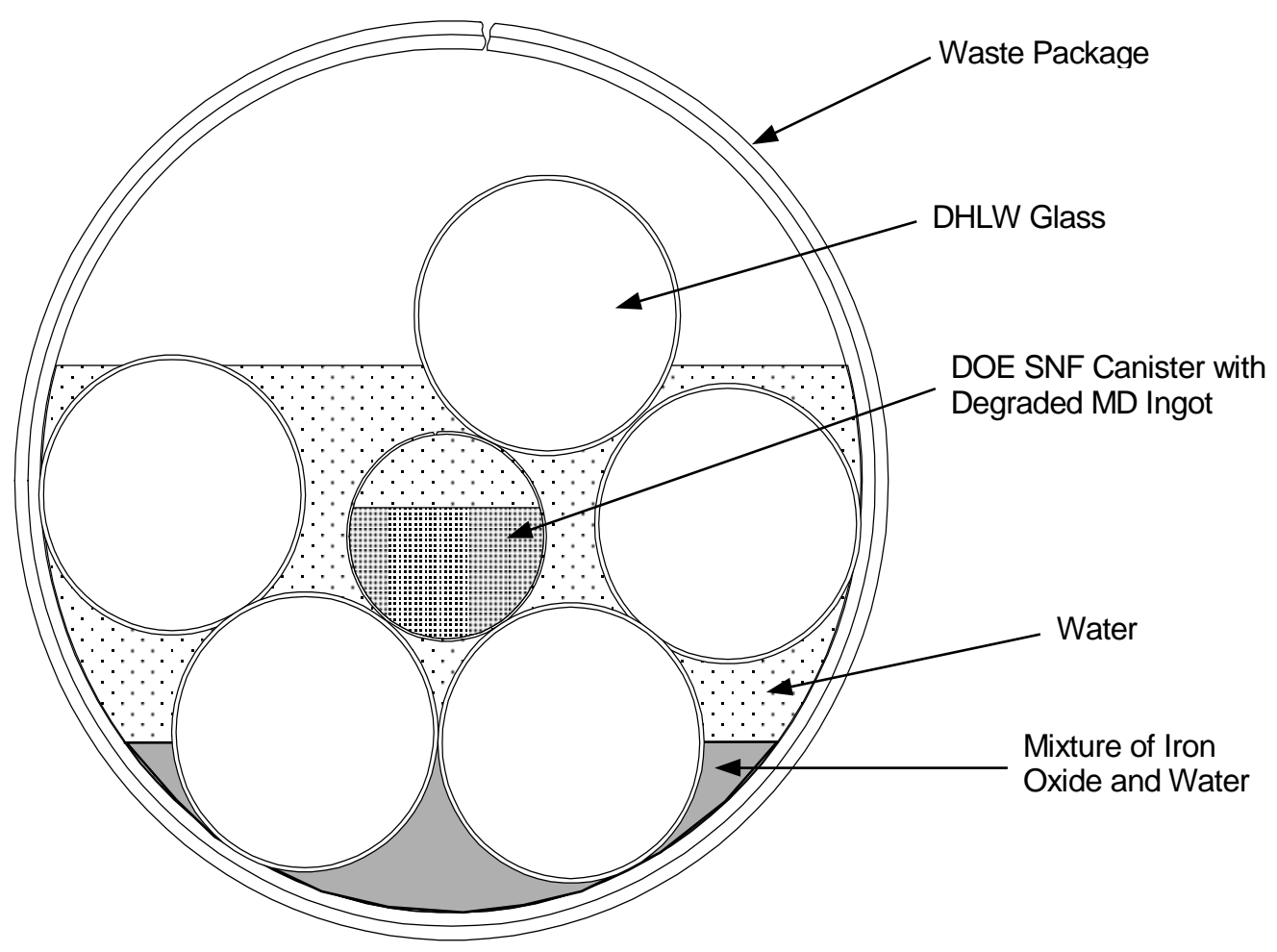

Figure 2.1 Conceptual Sketch of WP for Degradation Scenario IP-1 


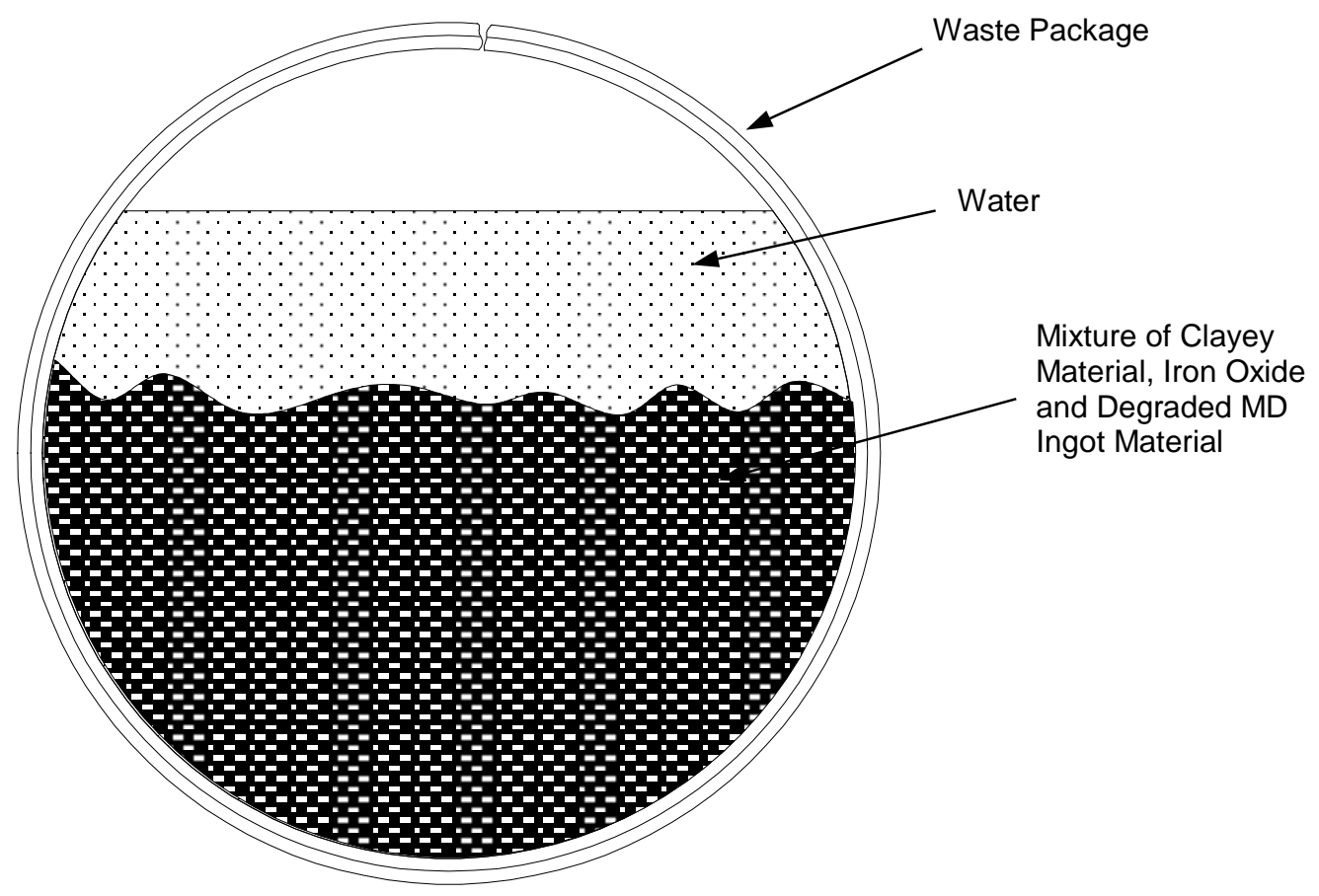

Figure 2.2 Conceptual Sketch of WP for Degradation Scenario IP-2

IP-3: The configurations resulting from IP-3 scenario (see Figure 2.3) for SNF degrading after OICs would require that the ingots have a low degradation rate and the $316 \mathrm{~L}$ stainless steel of the DOE SNF canister have substantially lower rates than the 304L stainless steel of the DHLW canisters, along with high degradation rates for the DHLW glass. In this configuration the ingots collect at the bottom of the WP while surrounded by degradation products (e.g., clayey material). As long as the ingots are intact there is no possibility for criticality since the neutron absorber is maintained. Loss of the neutron absorber $\left(\mathrm{GdPO}_{4}\right)$ if it enters solution and is flushed out of the WP while the fissile material is in a geometry that is favorable to criticality should be considered. Possible variations are configurations with DOE SNF canister degraded and intact SNF accumulated at the WP bottom with partial or total degradation of WP components. 


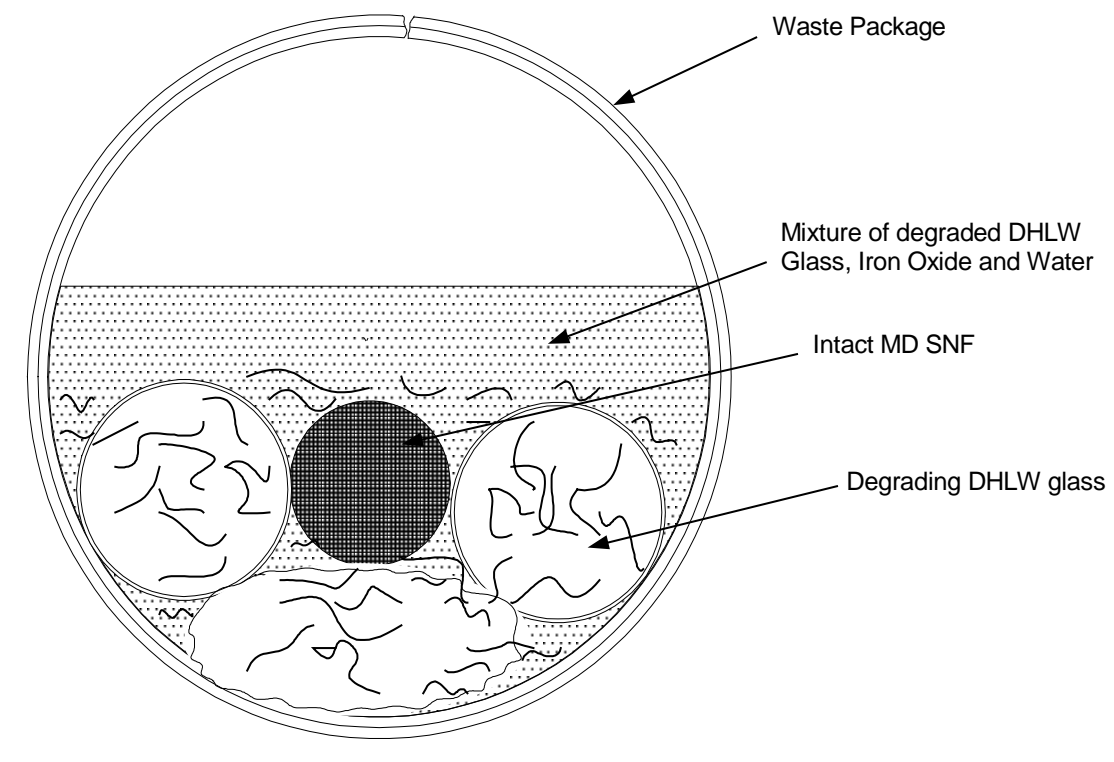

Figure 2.3 Conceptual Sketch of WP for Degradation Scenario IP-3

It should be noted that for the scenarios presented "flushing out of the neutron absorber" requires that water over-flows through the hole in the top of the WP.

Other degradation scenarios designated as IP-4, IP-5 and IP-6 that allow for water flow-through require a top and bottom breach in the waste package. However, for these scenarios to lead to potential critical configurations there must be some plugging of the hole(s) in the bottom, so that water can accumulate to provide neutron moderation. In addition, geochemistry calculations assume that a material does not get flushed out unless it is in solution. Therefore, the resulting configurations are the same as the configurations for the top breach only cases (IP-1, IP-2 and IP-3). 


\subsection{CRITICALITY ANALYSIS}

\subsection{Items Important to Criticality Control and Acceptance}

As part of the criticality licensing strategy, items that are important to criticality control will be identified during evaluation of the representative fuel types designated by the National Spent Nuclear Fuel Program. As a result of the analyses performed for the evaluation of the codisposal viability of Al-based DOEowned fuel, several items are identified as important to criticality control. The DOE SNF canister shell is naturally an item that is important to criticality control since it initially confines the fissile elements to a specific geometry and location within the waste package. The fissile mass limit in the canister, the linear density of the ${ }^{235} \mathrm{U}$ in the DOE SNF canister, and the fuel enrichment are also important to criticality control.

All calculations are based on a maximum of $38.3 \mathrm{~kg}{ }^{235} \mathrm{U}$ per DOE SNF canister. The degraded configurations of the Melt and Dilute ingots bound the other types of Al-based DOE-owned spent nuclear fuel, as long as the limits on mass of uranium and its enrichment, and the linear density are not exceeded.

Hence, the total mass of fissile element $\left({ }^{235} \mathrm{U}\right)$ should not exceed the mass used in deriving the conclusions of this report, which is $38.3 \mathrm{~kg}$ of ${ }^{235} \mathrm{U}$ per DOE SNF canister. The maximum ${ }^{235} \mathrm{U}$ enrichment is $20 \mathrm{wt} \%$. The linear density of the ${ }^{235} \mathrm{U}$ should not exceed $151 \mathrm{~g} / \mathrm{cm}$ in the DOE SNF canister. This value is calculated by considering the maximum diameter and the maximum $\mathrm{U}$ content $(18.2 \mathrm{wt} \%)$ for the MD ingots.

Table 3.1 indicates the relationships between the degradation scenarios described in Section 2.0 that could lead to removal of soluble neutron absorbers from the waste package and the geochemistry and criticality models (see Section 4.0). Criticality models to analyze the configuration classes shown are identified and discussed below.

\subsection{Computer Software}

The Monte Carlo particle transport code, MCNP, Version 4B2LV7, is used to estimate the effective neutron-multiplication factor $\left(\mathrm{k}_{\mathrm{eff}}\right)$ of the codisposal waste package. The information regarding the code and its use for the criticality analysis is documented in Reference 8.

The MCNP Version 4B2LV is used to estimate the $\mathrm{k}_{\text {eff }}$ values for various geometrical configurations of the MD SNF in the 5-DHLW/DOE SNF-short waste package. The $\mathrm{k}_{\text {eff }}$ results represent the average combined collision, absorption, and track-length estimator from the MCNP calculations. The standard deviation $(\sigma)$ represents the standard deviation of $\mathrm{k}_{\mathrm{eff}}$ related to the average combined collision, absorption, and track-length estimate due to the Monte Carlo calculation statistics. The calculations are performed using ENDF/B-V continuous energy cross-section libraries that are part of the qualified MCNP code system.

The MCNP calculated results are presented in the following sections to demonstrate that all foreseeable intact and degraded configurations inside the codisposal waste package have been investigated and the values of $k_{\text {eff }}$ are below the interim critical limit of 0.93. Although each of the degradation configurations discussed in Reference 4 is not specifically modeled, the criticality configurations selected were bounding type analyses and therefore extensive criticality sensitivity analyses were not necessary. 


\subsection{Intact Geometry Criticality Analysis}

This section presents the results of an intact-geometry mode criticality analysis representing a water intrusion situation. This criticality configuration (see Figure 3.1) represents a waste package, which has been breached, allowing inflow of water, and wherein the internal components of the waste package have maintained their as-loaded geometry. For all these calculations (unless otherwise specified), the waste package has reflected boundaries acting as a mirror (i.e., no neutron leakage) and represents a very conservative approach. Variations of postulated water intrusion were examined to identify the configuration that results in the highest calculated $\mathrm{k}_{\text {eff }}$ value for a range of possible water intrusion conditions. The results are shown in Table 3.1.

Intact cases were investigated first with a gadolinium loading of $0.5 \mathrm{wt} \%$ and the MD SNF form completely filling the DOE SNF canister. For these cases, approximately $212 \mathrm{~kg}$ of U and $5.8 \mathrm{~kg}$ of Gd are used. Cases were run with the MD ingot composition filling the interior of the DOE SNF canister and the $10 \%$ void in the MD ingots dry, half-filled, and filled with water. Ingot/gap height combinations from 10 to $60 \mathrm{~cm}$ high were also run to investigate the effects of ingot height. An additional case was evaluated to determine the effect of $2 \mathrm{wt} \% \mathrm{Si}$ in the MD ingot composition. This case simulates the composition of the MD-SNF form that is expected to result from the treatment of U-Al-Si base, Al-clad SNF.

The results show that the configuration with the wet ingot (10\% void in the MD ingots filled with water) has higher $\mathrm{k}_{\mathrm{eff}}+2 \sigma$ than the case with dry ingots. The addition of $2 \mathrm{wt} \% \mathrm{Si}$ in the MD ingot has negligible effect to criticality ( 0.3561 versus 0.3571 for case without $\mathrm{Si}$ ). The highest $\mathrm{k}_{\mathrm{eff}}+2 \sigma$ occurs for the case with the wet ingot filling the entire DOE SNF canister. For this case $k_{\text {eff }}+2 \sigma=0.3571$. Variation of ingot height $\mathrm{k}_{\mathrm{eff}}+2 \sigma$ results in a lower $\mathrm{k}_{\mathrm{eff}}+2 \sigma$. A highly moderated case without Gd in the waste package resulted in a $\mathrm{k}_{\mathrm{eff}}+2 \sigma$ below 0.90 , thereby confirming, for the water-filled but intact waste package, no Gd is required in the MD ingots to maintain subcriticality.

This finding is significant since it represents potential conditions prior to the onset of long-term degradation. The following sections discuss degraded conditions represented by the IP-1, IP-2, and IP-3 configurations described in Section 2.0. 
Table 3.1 Criticality Evaluation Summary for Degraded Configurations

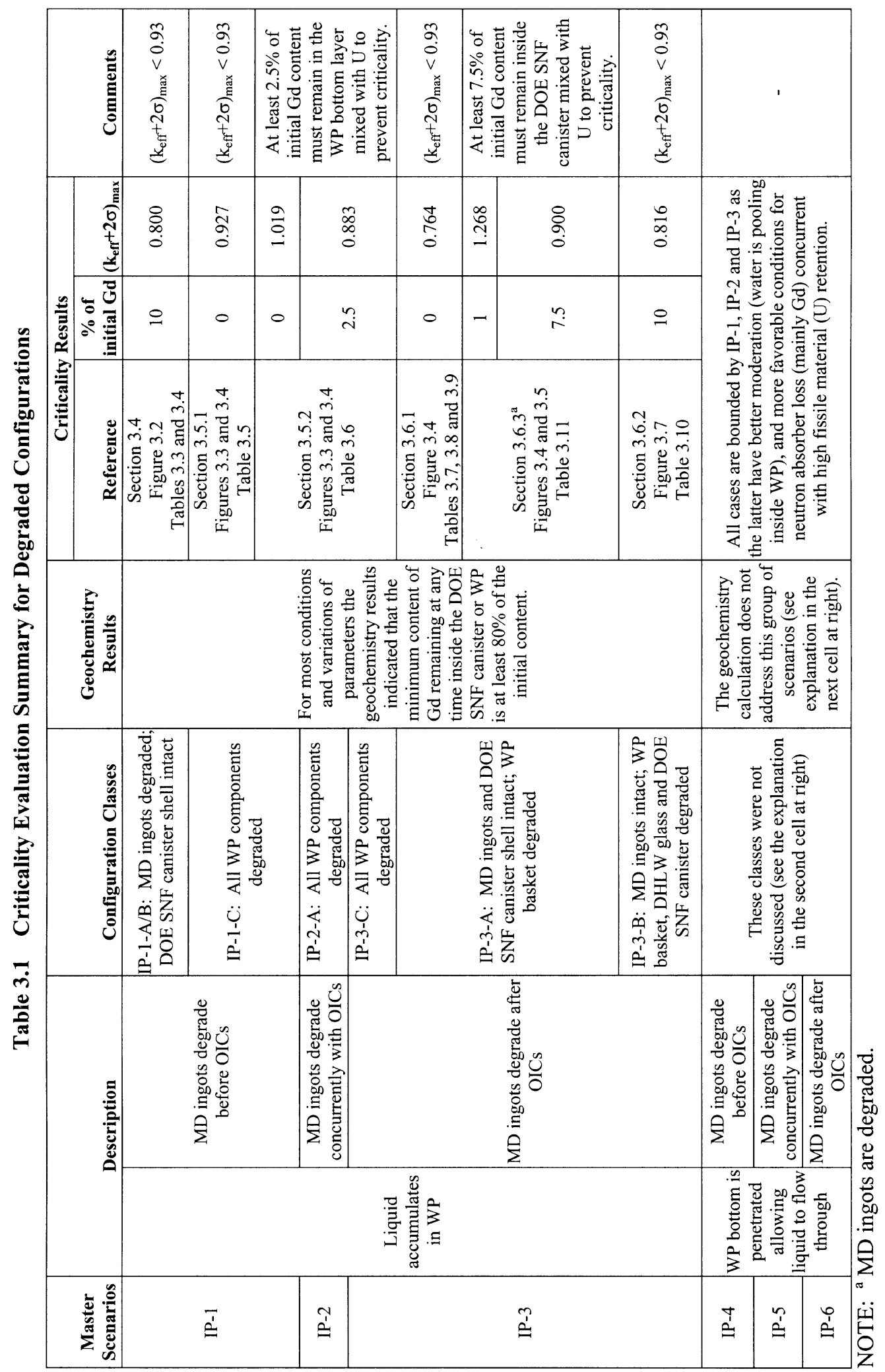




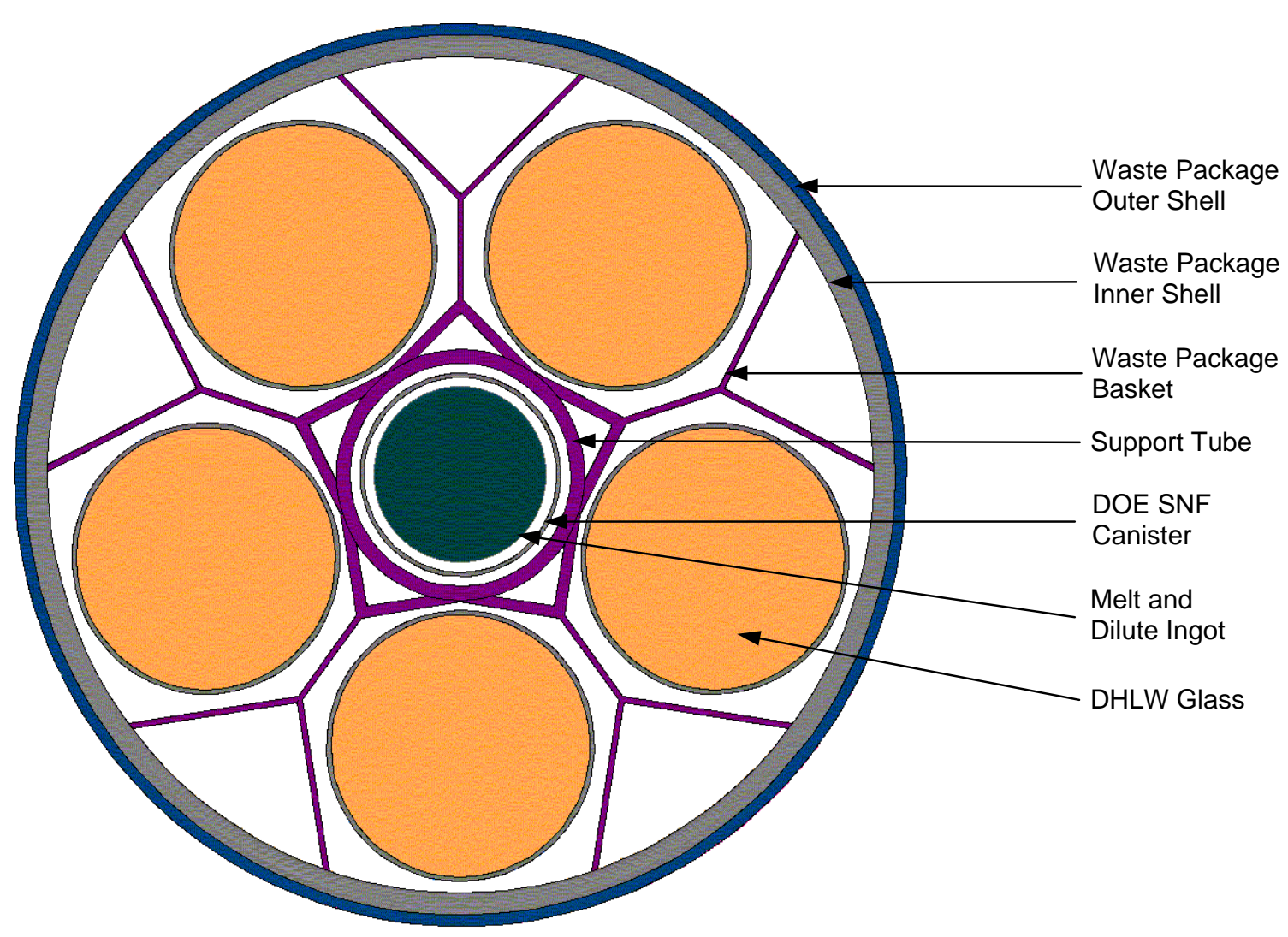

Figure 3.1 Cross-section View of the 5-DHLW/DOE Waste Package in an as-Loaded (intact) Configuration

Table 3.2 Results for Intact Mode Configurations

\begin{tabular}{|l|l|c|l|}
\hline \multicolumn{1}{|c|}{ Ingot Height } & \multicolumn{1}{|c|}{ Ingot Type } & wt\% Gd & $\mathbf{k}_{\text {eff }}+\mathbf{2} \sigma$ \\
\hline Full canister height & $\begin{array}{l}\text { Dry ingot } \\
\text { Dry waste package }\end{array}$ & 0.5 & 0.1521 \\
\hline Full canister height & Wet ingot & 0.5 & 0.3571 \\
\hline Full canister height & $\begin{array}{l}\text { Dry ingot } \\
\text { Filled waste package }\end{array}$ & 0.5 & 0.2155 \\
\hline Full canister height & Half-wet ingot & 0.5 & 0.2969 \\
\hline Full canister height & Wet ingot w/ $2 \mathrm{wt} \% \mathrm{Si}$ & 0.5 & 0.3561 \\
\hline $19 \mathrm{~cm}(1 \mathrm{~cm}$ water gap) & Wet ingot & 0.5 & 0.3475 \\
\hline $29 \mathrm{~cm}(1 \mathrm{~cm}$ water gap) & Wet ingot & 0.5 & 0.3464 \\
\hline $59 \mathrm{~cm}(1 \mathrm{~cm}$ water gap) & Wet ingot & 0.5 & 0.3450 \\
\hline $9 \mathrm{~cm}(1 \mathrm{~cm}$ water gap) & Wet ingot & 0.5 & 0.3482 \\
\hline $8 \mathrm{~cm}(2 \mathrm{~cm}$ water gap) & Wet ingot & 0.0 & 0.3014 \\
\hline $8 \mathrm{~cm}(2 \mathrm{~cm}$ water gap) & Wet ingot & & \\
\hline
\end{tabular}




\subsection{Waste Form Degrades Before the Internal Components of the Waste Package}

In this section, cases where the waste form degrades before any other internal components of the waste package are investigated and corresponds to configuration IP-1 (see Figure 2.1, Section 2.2). This configuration assumes a rapid degradation of the ingots in the canister while the rest of the waste package internals remain intact. For the purpose of the calculations presented in this section, the configuration shown in Figure 3.2 was used. This configuration is different from that of Figure 2.1 since most conservative features were added, i.e., the waste package internal components (but external to the DOE SNF canister) were considered intact and at the closest position relative to the DOE SNF canister and the waste package was filled with water (for best reflection and moderation). The uranium is conservatively represented in the form of $\mathrm{UO}_{2}$ that is distributed in the canister. The incorporation of $\mathrm{U}$ degradation products as $\mathrm{UO}_{2}$ maximizes the available volume for water, and thus, for $\mathrm{H}$. This $\mathrm{UO}_{2}$ is mixed with water, gibbsite $\left[\mathrm{Al}(\mathrm{OH})_{3}\right]$ and gadolinium. Above this MD bearing mixture is a mixture of water and gibbsite. In all the cases considered, various amounts of the ingot $\mathrm{Al}$ material were assumed to remain in the canister and $90 \%$ of the original gadolinium was assumed to be dissolved and removed. The amount of gibbsite that was removed from the canister was varied in order to observe the effects of different degrees of moderation. Cases were run with the height of the accumulation of degradation products in the canister varying from 10 to $40 \mathrm{~cm}$ (chord height in Table 3.3). For each height investigated the gibbsite fraction was varied from $100 \%$ to $0 \%$ of the original mass (water replaces gibbsite). The results in the geochemistry calculation indicate that less than $20 \%$ of the initial Gd content would be lost in this configuration $^{9}$, so these cases have a factor of 8 margin in Gd concentration. Degradation of most of the steel components would also be required to allow the loss of the Gd from the degraded MD ingots.

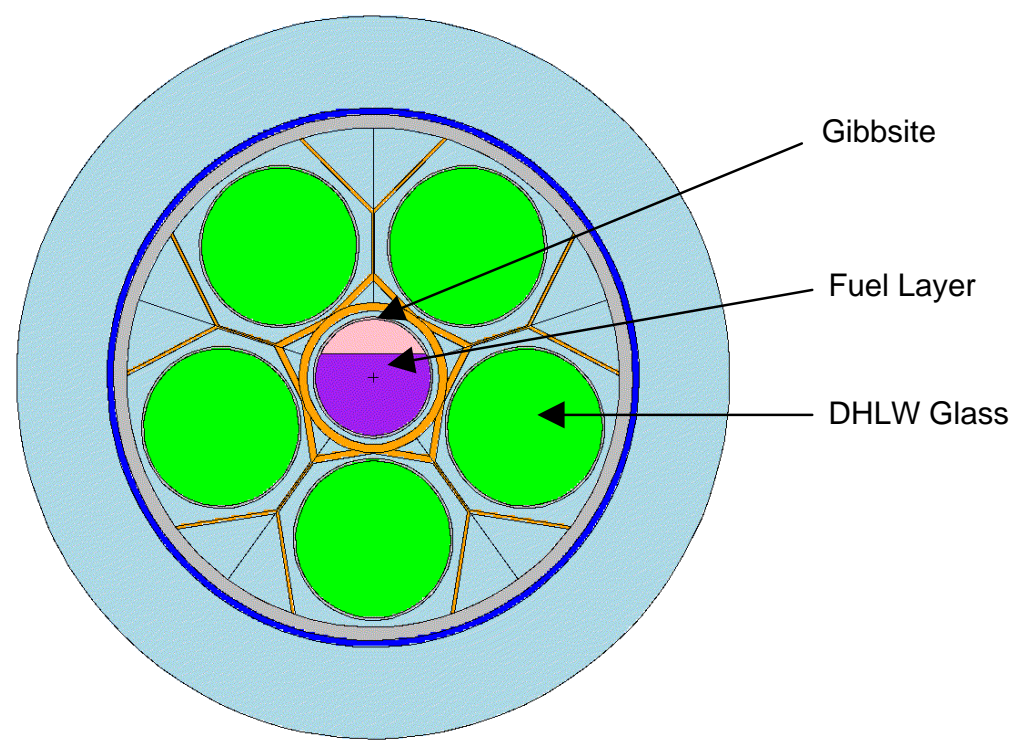

Figure 3.2 Cross-section View of Degraded Fuel in an Intact Waste Package

Table 3.3 shows results for criticality calculations where the void regions in the waste package are filled with water and the content of the gadolinium remaining in the waste package is chosen to be consistent with $90 \%$ of the original gadolinium leaving the system. Various mixtures of $\mathrm{UO}_{2}$, gibbsite, and water are run to identify optimum compositions. Water replaces gibbsite as the water fraction goes up. Table 3.4 shows results for calculations where the void regions of the waste package are left void. These cases have approximately $191.3 \mathrm{~kg}$ of $\mathrm{U}$ and $0.5 \mathrm{~kg}$ of $\mathrm{Gd}$ in the degraded fuel layer (constrained by the original 
dimensions of the ingots). The column titled water volume \% in Table 3.3 and Table 3.4, refers to the available volume after $\mathrm{UO}_{2}$ is considered.

Cases were run with the height of the accumulation of degradation products in the canister varying from 10 to $40 \mathrm{~cm}$. For each height investigated the gibbsite fraction was varied from $100 \%$ to $0 \%$ of the original mass in the space not occupied by $\mathrm{UO}_{2}$ (water replaces gibbsite) in the layer. The water fraction in the gibbsite/water layer above the $\mathrm{UO}_{2}$-bearing layer matches the $\mathrm{UO}_{2}$-bearing layer value. Under all circumstances $k_{\text {eff }}+2 \sigma$ remained under 0.80 with a factor of 8 margin on Gd mass as indicated by the geochemistry results, and the maximum value corresponds to a case with an accumulation $30 \mathrm{~cm}$ deep with all the gibbsite present. The cases with void space filled with water have slightly lower $k_{\text {eff }}+2 \sigma$ values than corresponding non-physical cases with empty void space.

Table 3.3 Results for Degraded Fuel in Intact DOE SNF Canister and Waste Package

\begin{tabular}{|c|c|c|}
\hline Chord Height (cm) & Water Volume \% & $k_{\mathrm{eff}}+2 \sigma$ \\
\hline 10 & 0 & 0.6609 \\
\hline 10 & 20 & 0.6791 \\
\hline 10 & 40 & 0.6743 \\
\hline 10 & 60 & 0.6736 \\
\hline 10 & 80 & 0.6694 \\
\hline 10 & 100 & 0.6699 \\
\hline 20 & 0 & 0.7507 \\
\hline 20 & 20 & 0.7671 \\
\hline 20 & 40 & 0.7612 \\
\hline 20 & 60 & 0.7610 \\
\hline 20 & 80 & 0.7559 \\
\hline 20 & 100 & 0.7488 \\
\hline 30 & 0 & 0.7852 \\
\hline 30 & 20 & 0.7822 \\
\hline 30 & 40 & 0.7782 \\
\hline 30 & 60 & 0.7804 \\
\hline 30 & 80 & 0.7712 \\
\hline 30 & 100 & 0.7682 \\
\hline 40 & 0 & 0.7818 \\
\hline 40 & 20 & 0.7816 \\
\hline 40 & 40 & 0.7766 \\
\hline 40 & 60 & 0.7800 \\
\hline 40 & 80 & 0.7757 \\
\hline 40 & 100 & 0.7740 \\
\hline
\end{tabular}

NOTE: In all cases the void inside waste package is filled with water. 
Table 3.4 Results for Degraded Fuel in Intact DOE SNF Canister and Waste Package

\begin{tabular}{|c|c|c|}
\hline Chord Height $(\mathrm{cm})$ & Water Volume \% & $k_{\text {eff }}+2 \sigma$ \\
\hline 10 & 0 & 0.6922 \\
\hline 10 & 20 & 0.6933 \\
\hline 10 & 40 & 0.6874 \\
\hline 10 & 60 & 0.6913 \\
\hline 10 & 80 & 0.6886 \\
\hline 10 & 100 & 0.6832 \\
\hline 20 & 0 & 0.7831 \\
\hline 20 & 20 & 0.7824 \\
\hline 20 & 40 & 0.7765 \\
\hline 20 & 60 & 0.7735 \\
\hline 20 & 80 & 0.7759 \\
\hline 20 & 100 & 0.7704 \\
\hline 30 & 0 & 0.7994 \\
\hline 30 & 20 & 0.7949 \\
\hline 30 & 40 & 0.7949 \\
\hline 30 & 60 & 0.7903 \\
\hline 30 & 80 & 0.7854 \\
\hline 30 & 100 & 0.7858 \\
\hline 40 & 0 & 0.7947 \\
\hline 40 & 20 & 0.7938 \\
\hline 40 & 40 & 0.7981 \\
\hline 40 & 60 & 0.7957 \\
\hline 40 & 80 & 0.7902 \\
\hline 40 & 100 & 0.7929 \\
\hline
\end{tabular}

NOTE: In all cases the void inside waste package is empty.

\subsection{All Components Internal to Waste Package Degraded}

These configurations represent the final stage of degradation (IP-2) at which time all components in the waste package have formed the geometry illustrated by Figure 3.3, and water surrounds the degraded package shown. Reference 9 gives the composition of the clay resulting from the degradation of the internal components of the waste package. This clay is referred as post-breach clay. If all of the $\mathrm{U}$ is eventually removed while $\mathrm{GdPO}_{4}$ remains there is no potential for criticality. However, if the $\mathrm{Gd}$ is removed before the $\mathrm{U}$ is all gone criticality can occur. Homogenizing the $\mathrm{Gd}$ in the clay will only increase its effectiveness in absorbing neutrons.

Table 6 of Reference 9 gives a post-breach degraded component composition for an alternative EQ3/6 case. In this case, the MD ingots degrade with the steel components of the waste package, but before the DHLW glass degrades and removes the U. However, since suppression of $\mathrm{GdPO}_{4}$ formation in the EQ3/6 calculations led to the removal of $\mathrm{Gd}$ before the $\mathrm{U}$ is removed (see Section 4.4), a number of criticality runs were made to investigate such sensitivities. 
MCNP cases were run where the amount of water in this mix is varied to determine the optimum moderation. The maximum water fraction in the fuel-bearing layer is very conservatively represented to be $50 \%$. Cases were run with a layer of $\mathrm{UO}_{2}$ mixed with water and for various mixtures of $\mathrm{UO}_{2}$, water, and degraded components. Determination of the minimum mass of Gd or $\mathrm{Hf}$ is made to cause the $\mathrm{k}_{\text {eff }}+2 \sigma$ to fall below 0.93. The geochemistry calculation demonstrates that Hf remains in the DOE SNF canister or waste package in each of the limited number of conditions considered. ${ }^{9}$

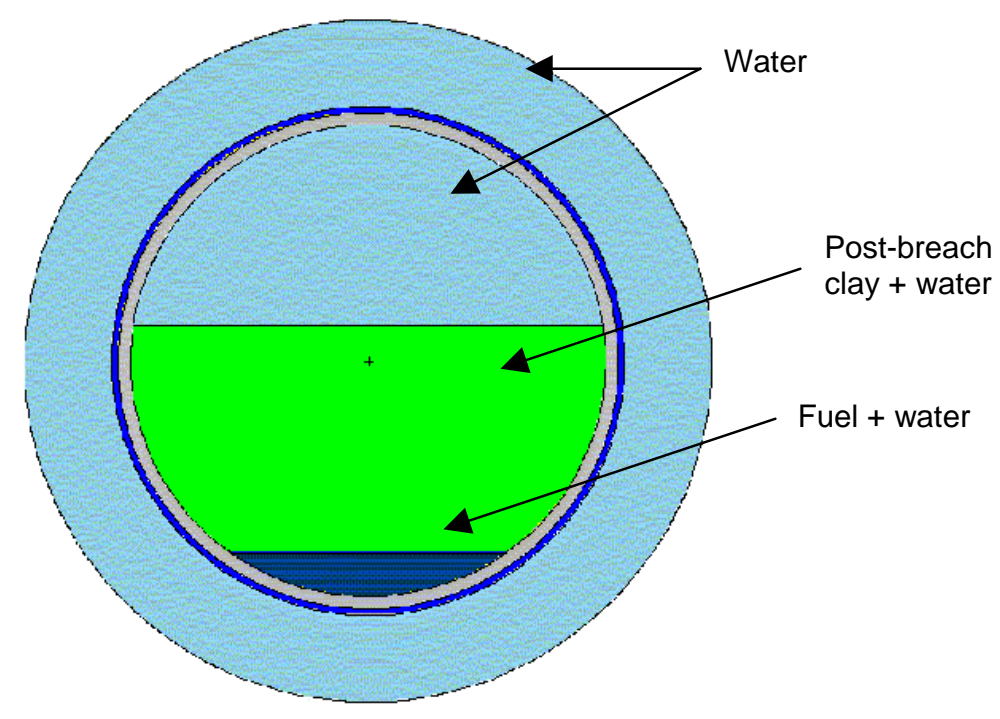

Figure 3.3 Cross-section View of WP with All Components Degraded

The effect of limited tilting of the waste package to the $k_{\text {eff }}+2 \sigma$ was also investigated for a tilt angle of $13.72^{\circ}$ as shown in Figure 3.4. The slope is chosen arbitrarily and the case included for completeness. 


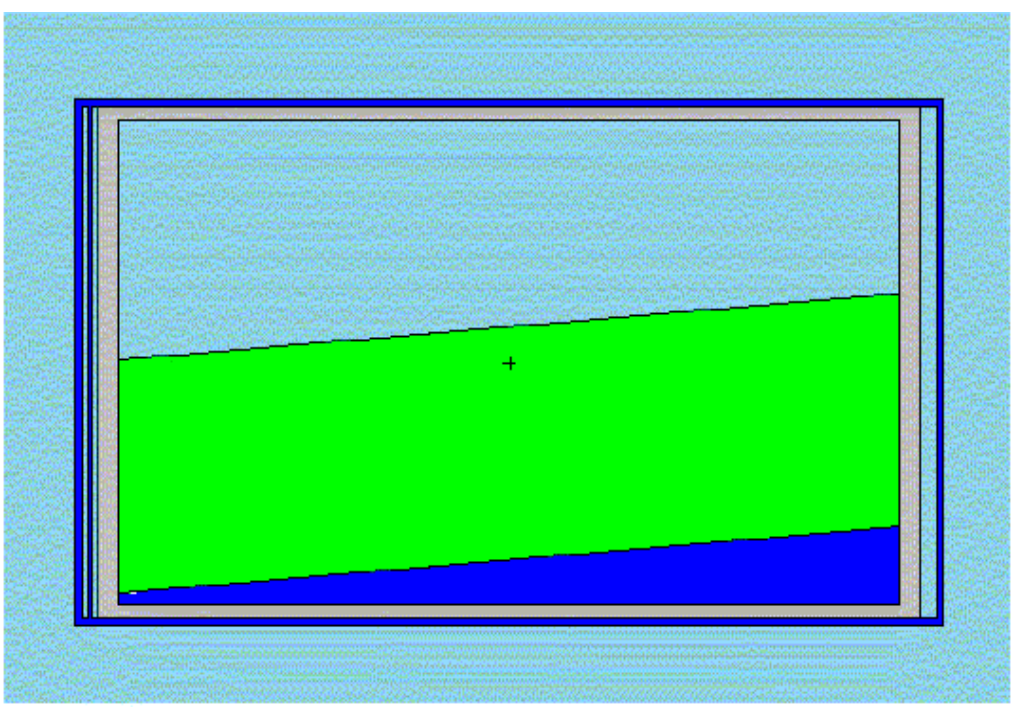

Figure 3.4 Cross-section View of Simulated Tilt of Waste Package

\subsubsection{Stratified Layers of $\mathrm{UO}_{2}$ and Post-breach Clay Without Neutron Absorber}

Table 3.5 shows results for cases comprised of a fuel layer $\left(\mathrm{UO}_{2}\right.$ and water) on bottom and clay layer on top. The cases are for $50 \%$ water content and $75 \%$ water content in the fuel layer, respectively and there is no neutron absorber in the fuel layer and are represented by Figure 3.3. These cases have $191.3 \mathrm{~kg}$ of $\mathrm{U}$ in the fuel layer.

Table 3.5 Results for Stratified $\mathrm{UO}_{2}$ and Clay Inside Waste Package

\begin{tabular}{|c|c|}
\hline Water Content $(\boldsymbol{\%})$ & $\mathbf{k}_{\text {eff }}+\mathbf{2} \boldsymbol{\sigma}$ \\
\hline 50 & 0.6949 \\
\hline 75 & 0.9270 \\
\hline
\end{tabular}

The result shows that there is no criticality concern for this particular configuration when the water content in the fuel layer is $50 \%$. The case with $75 \%$ water content in the fuel layer shows $k_{\text {eff }}+2 \sigma$ of 0.9270 , which is just below the critical limit. However, this configuration is not realistic due to lack of physical mechanism that could promote homogenization of $25 \% \mathrm{UO}_{2}$ with $75 \%$ water in stratified layers.

\subsubsection{Layers of Fuel Mixed with Clay}

Table 3.6 shows criticality analysis cases for a layer of $\mathrm{UO}_{2}$ mixed with the alternate post-breach clay composition corresponding to the extreme case where Gd is lost (see Sections 4.4 and 4.5) sitting on the bottom of the waste package as illustrated by Figure 3.3. This post-breach clay composition, without U, is on top. All these cases have $191.3 \mathrm{~kg}$ of $\mathrm{U}$ in the fuel layer. Following are cases to demonstrate the minimum mass of $\mathrm{Hf}$ and $\mathrm{Gd}$ required to prevent criticality. 
Table 3.6 Layers of Fuel Mixed with Clay

\begin{tabular}{|c|c|c|c|c|c|c|c|}
\hline \multirow[b]{2}{*}{ Case \# } & \multirow[b]{2}{*}{ Case Description } & \multirow{2}{*}{$\begin{array}{c}\text { Clay } \\
\text { Content } \\
(\text { vol } \%)\end{array}$} & \multirow{2}{*}{$\begin{array}{c}\text { Water } \\
\text { Content } \\
(\text { vol } \%)\end{array}$} & \multirow{2}{*}{$\begin{array}{c}\mathrm{UO}_{2} \\
\text { Content } \\
(\mathrm{vol} \%)\end{array}$} & \multicolumn{2}{|c|}{ Neutron Absorber } & \multirow[b]{2}{*}{$k_{\mathrm{eff}}+2 \sigma$} \\
\hline & & & & & Type & Content (g) & \\
\hline 1 & \multirow{10}{*}{$\begin{array}{c}\text { Configuration shown } \\
\text { in Figure } 3.3\end{array}$} & 25 & 50 & 25 & - & - & 0.8074 \\
\hline 2 & & 30 & 50 & 20 & - & - & 0.8490 \\
\hline 3 & & 40 & 50 & 10 & - & - & 0.9654 \\
\hline 4 & & 45 & 50 & 5 & - & - & 1.0182 \\
\hline 5 & & 47.50 & 50 & 2.50 & - & - & 0.9510 \\
\hline 6 & & 45 & 50 & 5 & $\mathrm{Gd}$ & 525.59 & 0.6642 \\
\hline 7 & & 45 & 50 & 5 & $\mathrm{Gd}$ & 262.8 & 0.7862 \\
\hline 8 & & 45 & 50 & 5 & $\mathrm{Gd}$ & 131.4 & 0.8825 \\
\hline 9 & & 45 & 50 & 5 & Hf & 525.59 & 1.0124 \\
\hline 10 & & 45 & 50 & 5 & $\mathrm{Hf}$ & 5255.9 & 0.9347 \\
\hline 11 & $\begin{array}{l}\text { Similar to case } 6 \text {, but the WP is } \\
\text { tilted } 13.72^{\circ}\end{array}$ & 45 & 50 & 5 & $\mathrm{Gd}$ & 525.59 & 0.7285 \\
\hline 12 & $\begin{array}{l}\text { Similar to case } 8 \text {, but } 30-\mathrm{cm} \\
\text { thick water is used as a reflector }\end{array}$ & 45 & 50 & 5 & $\mathrm{Gd}$ & 131.4 & 0.8096 \\
\hline 13 & $\begin{array}{l}\text { Similar to case } 8 \text {, but } 30-\mathrm{cm} \\
\text { thick tuff is used as a reflector }\end{array}$ & 45 & 50 & 5 & $\mathrm{Gd}$ & 131.4 & 0.8307 \\
\hline
\end{tabular}

Table 3.6 shows that approximately $2.5 \%$ of the original Gd loading $(131.4 \mathrm{~g})$ must remain with this mixture to prevent criticality or approximately $25 \%$ of the $\mathrm{Hf}$ (approximately $5 \mathrm{~kg}$ ) in the alternate MD ingot composition must remain. The geochemistry calculations (BSC 2001c) have demonstrated that Hf remains in the DOE SNF canister or waste package in each of the limited number of conditions considered. If confidence in the thermodynamic data for $\mathrm{GdPO}_{4}$ formation is not sufficient to make the loss of Gd incredible, then the MD ingot composition with Gd and Hf will prevent a critical condition.

The effect of tilting the waste package is investigated in case 11 (see Table 3.6), for the maximum tilt angle possible. The $\mathrm{k}_{\mathrm{eff}}+2 \sigma$ increased to 0.7285 , which is significantly less than the critical limit.

Replacing the reflective boundary condition with a $30-\mathrm{cm}$ thick water or tuff reflector decreases $\mathrm{k}_{\mathrm{eff}}+2 \sigma$. This shows that use of the reflective boundary condition for this case is very conservative.

\subsection{Internal Components of the Waste Package Degraded (outside intact DOE SNF canister) and Intact Ingots}

This section describes configurations resulting from the scenario IP-3 (see Figure 2.3, Section 2.2) For the purpose of the calculations presented in this section, the configuration shown in Figure 3.4 was used. This configuration is different from that represented by IP-3 (Figure 2.3) in the sense that the features considered most conservative were added, i.e. the waste package internal components (external to the DOE SNF canister, which was considered intact) were considered completely degraded into a homogeneous slurry in which the DOE SNF canister is completely immersed (for best reflection). The composition of the slurry is given in Table 6 of Reference 9 and is referenced as the pre-breach clay. The amount of water mixed in this clay varies. There is ${ }^{238} \mathrm{U}$ present in the slurry from the degraded glass, but it is neglected in these calculations. The MD ingot-bearing canister is assumed to have dropped down to 
the bottom of the waste package and is surrounded by a mixture of water and clay. The geometrical configuration is shown in Figure 3.5. Although the DOE SNF canister and MD ingots are assumed intact, they are also assumed fully flooded with water, which was determined to be the most reactive composition. Since the MD ingot is flooded, it is assumed $10 \%$ water by volume. This conservatively bounds the dry ingot case, since filling the porosity with water will increase (to the maximum limit) the moderation of the already under-moderated intact ingots. Both the gadolinium content of the ingots and the water volume fraction in the clay were varied. The density of dry pre-breach clay is $3.682 \mathrm{~g} / \mathrm{cm}^{3}$.

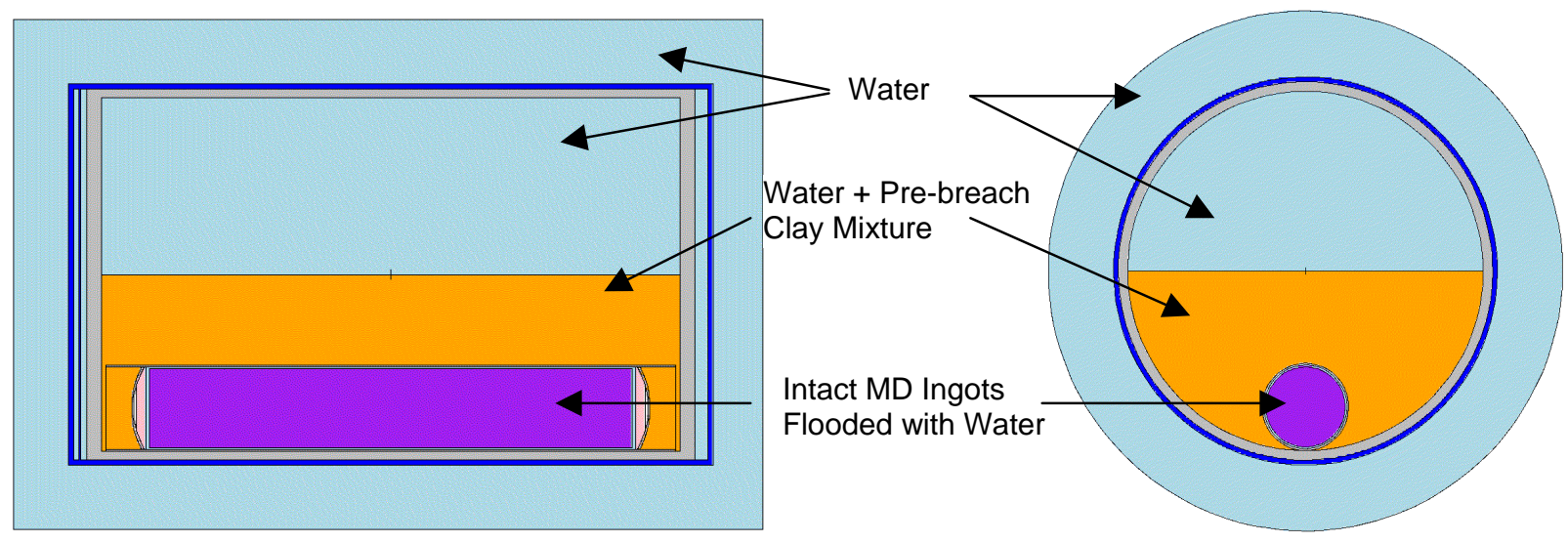

\section{Figure 3.5 Cross-section Views of Intact DOE SNF Canister Degraded Internal Waste Package Components}

The next stage of degradation involves the configuration described above with the degraded MD ingots within the DOE SNF canister as discussed in Section 3.4. The most conservative conditions identified in the previous calculations were used to characterize this combination. The minimum mass of Gd required to remain in the canister was identified and the effect of thinning the canister wall was investigated. Another case was run to simulate the effect of tilting of the DOE SNF canister inside the waste package as shown in Figure 3.6. The volume of the fuel region was conserved while the tilt angle was chosen as the maximum tilt that is conceivable for the DOE SNF canister inside the waste package, which is $13.72^{\circ} .^{8}$

A bounding additional configuration was considered where ingots form an array inside the waste package and are surrounded by water as shown in Figure 3.7. The gadolinium linear density was chosen to be consistent with $90 \%$ of the original gadolinium leaving the system. Calculation was performed for short ingots $(25.4 \mathrm{~cm})$ forming an array with 9 units and for long ingots $(76.2 \mathrm{~cm})$ forming a array with 3 units inside the waste package. 


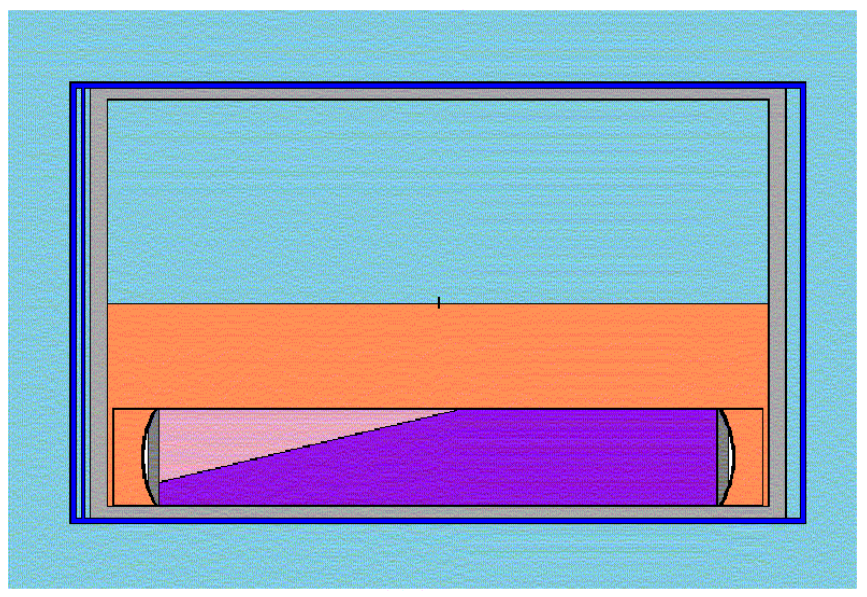

Figure 3.6 Cross-section View of Simulated Tilt of Intact DOE SNF Canister with Degraded Fuel and Degraded Internal Waste Package Components

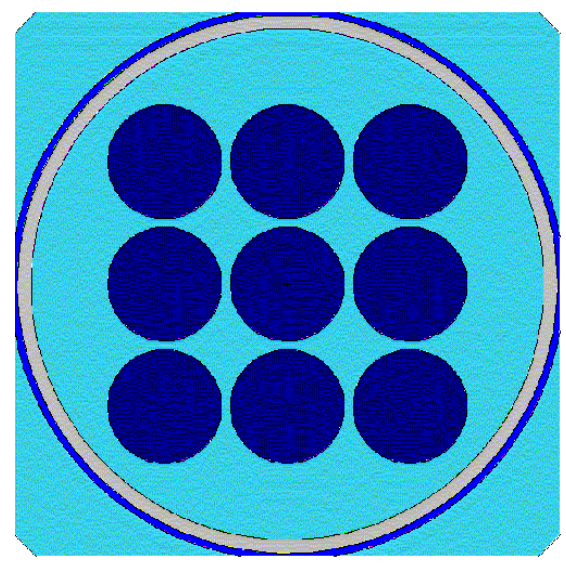

Figure 3.7 Array of 9 Ingots Inside the Waste Package Surrounded with Water

\subsubsection{Wet Intact Ingots with Full or Partial Gd}

Table 3.7 presents the results of the calculations for wet ingots with full Gd content of $0.5 \mathrm{wt} \%$ (5.8 kg/waste package) and a U content of $212 \mathrm{~kg}$, corresponding to the MD fuel form completely filling the canister. The composition of the wet intact ingots is as described in Section 3.6 and corresponds to the highest $\mathrm{k}_{\mathrm{eff}}$ values in Section 3.3. The basic case is illustrated in Figure 3.5, which shows the DHLW glass canisters and all the basket structure as degraded and forming a layer of pre-breach clay surrounding the DOE SNF canister. 
Table 3.7 Wet Ingots with Full Gd Content

\begin{tabular}{|c|c|}
\hline $\begin{array}{c}\text { Water Content in Clay } \\
\text { (volume } \% \text { ) }\end{array}$ & $\mathbf{k}_{\text {eff }}+\mathbf{2} \boldsymbol{\sigma}$ \\
\hline 0 & 0.4264 \\
\hline 20 & 0.3934 \\
\hline 40 & 0.3736 \\
\hline 60 & 0.3589 \\
\hline 80 & 0.3521 \\
\hline 100 & 0.3428 \\
\hline
\end{tabular}

$\mathrm{k}_{\mathrm{eff}}+2 \sigma$ is highest for the case when there is no water present in the pre-breach clay.

Table 3.8 presents the results of the calculations for wet ingots with partial Gd content of $0.05 \mathrm{wt} \%$ $(0.58 \mathrm{~kg} / \mathrm{WP})$ and the MD fuel form completely filling the canister.

Table 3.8 Wet Ingots with Partial Gd Content

\begin{tabular}{|c|c|}
\hline $\begin{array}{c}\text { Water Content in Clay } \\
\text { (volume \%) }\end{array}$ & $\mathbf{k}_{\text {eff }}+\mathbf{2} \boldsymbol{\sigma}$ \\
\hline 0 & 0.6075 \\
\hline 20 & 0.5601 \\
\hline 40 & 0.5335 \\
\hline 60 & 0.5146 \\
\hline 80 & 0.5005 \\
\hline 100 & 0.4949 \\
\hline
\end{tabular}

Again, $\mathrm{k}_{\text {eff }}+2 \sigma$ is highest for the case when there is no water in the pre-breach clay.

Table 3.9 presents the results of the calculations for wet ingots with partial Gd content of $0.025 \mathrm{wt} \%$ $(0.29 \mathrm{~kg} / \mathrm{WP}), \mathrm{Gd}$ content of $0.0025 \mathrm{wt} \%(0.029 \mathrm{~kg} / \mathrm{WP})$ for the next before the last case and no Gd for the last case. The MD fuel form is filling the canister completely.

Table 3.9 Wet Ingots with Low Gd Content

\begin{tabular}{|c|c|c|}
\hline $\begin{array}{c}\text { Water Content in Clay } \\
\text { (volume \%) }\end{array}$ & $\begin{array}{c}\text { Gd Content } \\
\text { (g/WP) }\end{array}$ & $\mathbf{k}_{\text {eff }}+\mathbf{2} \boldsymbol{\sigma}$ \\
\hline 0 & 263 & 0.6586 \\
\hline 20 & 263 & 0.6083 \\
\hline 40 & 263 & 0.5840 \\
\hline 60 & 263 & 0.5653 \\
\hline 80 & 263 & 0.5530 \\
\hline 100 & 263 & 0.5476 \\
\hline 0 & 26.3 & 0.7503 \\
\hline 0 & 0 & 0.7634 \\
\hline
\end{tabular}


$\mathrm{k}_{\mathrm{eff}}+2 \sigma$ is highest for the case when there is no water in the pre-breach clay. Even without any Gd in the waste package $\mathrm{k}_{\mathrm{eff}}+2 \sigma$ is well below 0.93 .

\subsubsection{Intact Melt and Dilute Ingots in the Waste Package}

Table 3.10 shows results for cases of ingots forming an array inside the waste package. The maximum value of $k_{\text {eff }}+2 \sigma$ is 0.8157 for case with 3 ingots. The first case is an array of 9 short ingots as shown in Figure 3.7 and the second case is for 3 long ingots. The ingots are sized such that they all fit within the DOE SNF canister. These cases have $0.05 \mathrm{wt} \% \mathrm{Gd}$.

Table 3.10 Results for Array of Ingots Inside Waste Package

\begin{tabular}{|c|c|}
\hline Ingot Length $(\mathbf{c m})$ & $\mathbf{k}_{\text {eff }} \mathbf{+ 2} \boldsymbol{\sigma}$ \\
\hline 25.4 & 0.7257 \\
\hline 76.2 & 0.8157 \\
\hline
\end{tabular}

\subsubsection{Degraded Melt and Dilute Ingots}

This configuration has degraded ingots within the intact DOE SNF canister as described in Section 3.4, but with degraded waste package internals. This configuration would be similar to the one shown in Figure 3.4, but with degraded MD ingots. The composition with which the highest $\mathrm{k}_{\mathrm{eff}}+2 \sigma$ values are associated from Section 3.4 is used (the case in Table 3.4 with a chord height of $30 \mathrm{~cm}$ and a water volume of $0 \%$ ). The pre-breach clay with $0 \%$ water, with which the highest $\mathrm{k}_{\text {eff }}$ values are associated in Section 3.4 is used. Table 3.11 presents the results for this configuration. These cases have approximately $191.3 \mathrm{~kg}$ of $\mathrm{U}$. The initial case has $10 \%$ of the original Gd loading.

Table 3.11 Degraded Ingots in Intact DOE SNF Canister with Degraded Waste Package Internals

\begin{tabular}{|c|c|c|c|c|}
\hline \multirow{2}{*}{$\begin{array}{c}\text { Case } \\
\#\end{array}$} & \multirow[b]{2}{*}{ Case Description } & \multicolumn{2}{|c|}{ Gd Content in WP } & \multirow[b]{2}{*}{$k_{\text {eff }}+2 \sigma$} \\
\hline & & \% of Initial Gd & (g) & \\
\hline 1 & \multirow{5}{*}{$\begin{array}{l}\text { Degraded Ingots in the DOE SNF Canister and Intact Waste } \\
\text { Package (chord height is } 30 \mathrm{~cm} \text { and water volume } 0 \% \text { ) }\end{array}$} & 10.0 & 525.59 & 0.8161 \\
\hline 2 & & 7.5 & 394.19 & 0.8914 \\
\hline 3 & & 5.0 & 262.80 & 1.0031 \\
\hline 4 & & 2.5 & 131.40 & 1.1425 \\
\hline 5 & & 1.0 & 52.56 & 1.2678 \\
\hline 6 & $\begin{array}{l}\text { Similar to case 2, but the DOE SNF canister wall thinned to } \\
\qquad 0.3175 \mathrm{~cm}\end{array}$ & 7.5 & 394.19 & 0.8940 \\
\hline 7 & Similar to case 1, but the DOE SNF canister is tilted $13.72^{\circ}$ & 10.0 & 525.59 & 0.8443 \\
\hline 8 & Similar to case 2 , but $30-\mathrm{cm}$ thick water is used as a reflector & 7.5 & 394.19 & 0.8810 \\
\hline 9 & Similar to case 2 , but $30-\mathrm{cm}$ thick tuff is used as a reflector & 7.5 & 394.19 & 0.8810 \\
\hline
\end{tabular}

The results show that retention of at least $7.5 \%$ of the original Gd inventory assures $k_{\text {eff }}+2 \sigma$ below 0.93 , but reducing the Gd inventory below this value could result in values significantly over 1.0. Comparing the results of the first case in Table 3.10 with those for the case in Table 3.4 with a chord height of $30 \mathrm{~cm}$ and a water volume of $0 \%$, leads to the observation that the current configuration is bounding.

The thinning of the canister wall down from $0.9525 \mathrm{~cm}$ to $0.3175 \mathrm{~cm}$ increases $\mathrm{k}_{\mathrm{eff}}+2 \sigma$ by less than $1 \%$ $\left(\mathrm{k}_{\mathrm{eff}}+2 \sigma\right.$ of 0.8915 versus 0.8850 ). The effect of a $13.72^{\circ}$ tilt (for the first case in Table 3.10) to $\mathrm{k}_{\text {eff }}+2 \sigma$ is an increase of approximately $1.5 \%$. 
Replacing the reflective boundary condition with a 30-cm water or tuff reflector (cases 8 and 9 in Table 3.11, respectively) decreases $\mathrm{k}_{\mathrm{eft}}+2 \sigma$. This shows that use of the reflective boundary condition is slightly conservative.

\subsection{Most Probable Degradation Path}

Based on the corrosion rates and the material thickness given in Table 3.12 and Table 3.13, respectively, the most probable degradation path for the waste package, the DOE SNF canister, and the MD ingots follows the sequence below:

1. Waste package is penetrated and flooded internally. Water has not yet penetrated the DOE SNF canister (see Table 3.1) for the results of criticality calculations for this configuration).

2. The waste package separation plates and DOE SNF canister support cylinder degrade first because of the high corrosion rate of A516 carbon steel. Degraded steel product (iron oxide) accumulates at the bottom of the waste package (criticality calculations in Section 3.3 are bounding for this configuration).

3. DHLW glass canister shell degrades and exposes the DHLW glass. The DHLW glass degrades at a much lower rate than the stainless steel components and only a small percentage degrades while the stainless steel degrades as demonstrated in the geochemistry calculations. ${ }^{9}$ There are two possible degradation paths:

3.a. DOE SNF canister stays intact. Intact DOE SNF canister with intact MD ingots fall and are surrounded by the iron-rich degradation products near the bottom of the waste package (see Section 3.6.2 for criticality calculations results and Figures 3.5 and 3.6 for configurations).

3.b. DOE SNF canister starts to degrade.

Following $3 \mathrm{~b}$ above, DOE SNF canister shell is penetrated but remains intact and DOE SNF canister interior is flooded (Section 3.6, Figure 3.5, and Figure 3.6 cover this case).

4. MD ingots in the DOE SNF canister are in contact with water. MD ingots start to degrade due to their high corrosion rate. The MD ingots degrade into hydrated $\mathrm{Al}$ and $\mathrm{U}$ oxides and Gd phosphate (see Section 3.6.3 for criticality calculations results and Figure 3.5 and Figure 3.6 for configurations).

5. DOE SNF canister shell completely degrades. The degraded iron oxide mixes with the small percentage of degraded glass clay at the bottom of the waste package. The degraded MD ingot material falls out and scatters on top of or mixes with the clay/iron oxide mixture (see Section 3.4 for criticality calculations results and Figure 3.3 and Figure 3.4 for configurations).

6. Degraded glass clay product accumulates at the bottom of the waste package over or mixed with the iron-rich degradation products from the other OICs and the MD ingots (covered in Section 3.4).

A variation of the above sequence would retain the DOE SNF canister and subsequent degradation products trapped in the center of the DHLW glass logs, but the result is essentially the same.

Given a very long period of time, it is postulated that everything will degrade. All the internal components of the waste package will then be represented as sludge. This corresponds to degradation scenario group IP-2. The degraded MD ingots and other degradation products could mix and pile up near 
the bottom of waste package. However, there is no mechanism to cause complete and uniform mixing of all the degradation products inside the waste package.

Table 3.12 Properties of Materials in Melt and Dilute Codisposal Waste Package

\begin{tabular}{|c|c|c|c|c|}
\hline \multirow[b]{3}{*}{ Reactant } & \multicolumn{3}{|c|}{$\boldsymbol{R k}$} & sk \\
\hline & \multicolumn{3}{|c|}{ Reaction Rate $\left(\mathrm{mol} / \mathrm{cm}^{2} \cdot \mathrm{s}\right)$} & \multirow{2}{*}{$\begin{array}{c}\text { Surface Area } \\
\left(\mathrm{cm}^{2}\right)\end{array}$} \\
\hline & 1 & 2 & 3 & \\
\hline DHLW Glass & $\begin{array}{c}\text { rk1 }=8.858 \mathrm{E}-19 \\
\mathrm{cdac} 1=-0.4 \\
\mathrm{rk} 2=7.976 \mathrm{E}-13 \\
\mathrm{cdac} 2=0.6\end{array}$ & $\begin{array}{c}\mathrm{rk} 1=1.076 \mathrm{E}-17 \\
\mathrm{cdac} 1=-0.4 \\
\mathrm{rk} 2=4.874 \mathrm{E}-12 \\
\mathrm{cdac} 2=0.6\end{array}$ & $\begin{array}{c}\text { Not } \\
\text { Applicable } \\
(\mathrm{N} / \mathrm{A})\end{array}$ & 1228.64 \\
\hline Ingots & 1.399E-14 & $2.536 \mathrm{E}-13$ & $4.830 \mathrm{E}-12$ & 11.66 \\
\hline A516 Ingot Liner & $1.798 \mathrm{E}-11$ & $\mathrm{~N} / \mathrm{A}$ & $\mathrm{N} / \mathrm{A}$ & 24.60 \\
\hline 304L Glass Pour Canister & $2.520 \mathrm{E}-14$ & $2.520 \mathrm{E}-13$ & $8.656 \mathrm{E}-12$ & 141.5 \\
\hline A516 Outer Web & $1.798 \mathrm{E}-11$ & $\mathrm{~N} / \mathrm{A}$ & $\mathrm{N} / \mathrm{A}$ & 120.0 \\
\hline A516 Impact Plates & $1.798 \mathrm{E}-11$ & $\mathrm{~N} / \mathrm{A}$ & $\mathrm{N} / \mathrm{A}$ & 1.615 \\
\hline 316L DOE SNF Canister & $2.530 \mathrm{E}-14$ & $2.530 \mathrm{E}-13$ & $5.056 \mathrm{E}-13$ & 22.67 \\
\hline 316NG Inner Shell & $2.530 \mathrm{E}-14$ & $2.530 \mathrm{E}-13$ & $5.056 \mathrm{E}-13$ & 57.3 \\
\hline
\end{tabular}

The degradation rates in Table 3.12 range from low to high (indicated by " 1 " to " 3 "). The true reaction rate is obtained by multiplying the reaction rate $(r k)$ by the surface area $(s k)$ to get mol/s. Inspection of the rates show that for a comparable surface area, the A516 carbon steel is expected to degrade much more rapidly than the stainless steels $(316 \mathrm{~L}, 316 \mathrm{NG}$, and 304L). The ingot rate 1, from Reference 10, is the degradation rate given for $\mathrm{U}-\mathrm{Al}$ fuel types. The ingot rate 2 is the degradation rate of pure aluminum 1100 .

The outer web is composed of A-516 carbon steel, and serves two purposes: it centers, holds in place, and separates the DOE Canister and the GPCs; and prevents them from transmitting undue stress to each other in the event of a fall (tip-over) of the entire WP. In a breach scenario, the A516 WP components will be exposed to water and corrode before the rest of the WP, and are expected to degrade within a few hundred to a few thousand years.

Table 3.13 Materials and Thickness

\begin{tabular}{|l|c|c|}
\hline \multicolumn{1}{|c|}{ Components } & Material & Thickness (mm) \\
\hline Waste package divider plate & A516 Carbon Steel & 12.7 \\
\hline Waste package support tube & A516 Carbon Steel & 31.75 \\
\hline High-level waste glass canister shell & 304L Stainless Steel & 9.525 \\
\hline High-level waste glass & Glass & N/A \\
\hline DOE SNF canister shell & 316L Stainless Steel & 9.525 \\
\hline MD ingots & U-Al alloy & $381-419$ \\
\hline
\end{tabular}




\subsection{Intact and Degraded Component Criticality Conclusions}

The criticality analyses considered all aspects of intact and degraded configurations of the codisposal waste package containing Melt and Dilute ingots, including optimum moderation condition, optimum reflection, geometry and composition. The results of three-dimensional Monte Carlo criticality calculations for the intact configuration show that the requirement of $k_{\text {eff }}+2 \sigma$ values less than or equal to the interim critical limit of 0.93 is satisfied for the MD codisposal package. The criticality calculations results for all anticipated degraded-mode configurations developed through the degradation analysis show that the requirement of $\mathrm{k}_{\mathrm{eff}}+2 \sigma$ values less than or equal to the interim critical limit of 0.93 is satisfied for the MD codisposal package if at least $7.5 \%$ of the original Gd loading (394.2 $\mathrm{g}$ ) in the ingots without Hf remains mixed with the fissile material. In the alternate MD ingot composition (containing $2.5 \mathrm{wt} \% \mathrm{Hf}$ ), Hf remains in the DOE SNF canister or waste package in each of the limited number of conditions considered, therefore preventing a critical condition even if all $\mathrm{Gd}$ is removed from the system. 


\subsection{GEOCHEMISTRY ANALYSIS CONSIDERATIONS}

\subsection{Computer Software}

Geochemistry analyses were performed using the EQ3/6 Version 7.2bLV ${ }^{11-12}$ geochemistry software package in the solid-centered flow-through mode. The information regarding the code and its use for the degradation and geochemistry analysis is documented in Reference 9.

A principal objective of the geochemistry calculations was to assess the chemical circumstances that could lead to removal of neutron absorbers (mainly Gd) from a waste package containing MD ingots (AlSNF) and DHLW glass, while fissile materials (U) remain behind. Such circumstances could increase the probability of a nuclear criticality occurrence within the waste package. EQ6 reaction path calculations were carried out to span the range of possible system behavior and to assess the specific and coupled effects of MD ingots degradation, steel corrosion, DHLW glass degradation, and fluid influx rate on U mobilization. Corrosion product accumulation was examined as well. The results presented in Reference 9, and summarized in this section, have been used as inputs to the criticality calculations described in Section 2.0 of this document.

\subsection{Basic Design Approach for Geochemistry Analysis}

The method used for this analysis involves eight steps as described below:

- Use the basic EQ3/6 capability to trace the progress of reactions as the chemistry evolves, including estimating the concentrations of material remaining in solution as well as the composition of precipitated solids. EQ3 is used to determine a starting fluid composition for EQ6 calculations; it does not simulate reaction progress.

- Evaluate available data on the range of dissolution rates for the materials involved to be used as material/species input for each time step.

- Use the "solid-centered flow-through" mode in EQ6. In this mode, an increment of aqueous "feed" solution is added continuously to the waste-package system, and a like volume of the existing solution is removed. This mode simulates a continuously stirred tank reactor.

- Determine the concentrations of fissile material in solution as a function of time (from the output of EQ6 simulated reaction times up to $\sim 6 \times 10^{5}$ years).

- Calculate the amount of fissile material released from the waste package as a function of time (which, thereby, reduces the chance of criticality within the waste package).

- Determine the concentrations of neutron absorbers (most importantly Gd) in solution as a function of time (from the output of EQ6 over times up to $\sim 6 \times 10^{5}$ years).

- Calculate the amount of neutron absorbers retained within the waste package as a function of time.

- Calculate the composition and amounts of solids (precipitated minerals or corrosion products and unreacted waste package materials).

\subsection{Geochemistry Degradation Calculations and Results}

The calculations begin using selected representative values from known ranges for composition, amounts, surface areas, and reaction rates of the various components of the MD waste packages. The input to EQ6 
includes the composition of $\mathrm{J}-13$ well water, a rate of influx to the waste package that corresponds to suitably chosen percolation rates into a drift, and a drip rate into the waste package, which is also the flow rate out of the waste package. In some cases, the degradation of the waste package is divided into stages (e.g., degradation of the DHLW glass before breach of the DOE SNF canister and exposure of the ingot material to the water). The EQ6 outputs include the compositions and amounts of solid products and the solution composition. The calculation process is presented in more detail in Reference 9.

Table 4.1 illustrates representative analysis cases that explore the different sequences of degradation: degrading the glass first and then the ingots, the ingots first and then the glass, or degrading the glass and ingots together.

Table 4.1 Cases Varying the Sequence of Degradation

\begin{tabular}{|c|c|c|c|c|c|}
\hline \multirow[t]{2}{*}{ md02_01 } & \multicolumn{5}{|c|}{$\begin{array}{l}\text { Maximum volume of ingots that fit in a DOE SNF canister with a minimum ingot liner thickness }(1 \mathrm{~mm}) \text {. } \\
2 \text { stage run: Degrade glass and then expose ingots. High glass and drip rates, low ingot and SS rates. }\end{array}$} \\
\hline & Reactant Fully Degraded & Time (years) & pH & $\%$ Gd Remaining & $\%$ U Remaining \\
\hline & Glass & 14,839 & 8.81 & $100.00 \%$ & $55.85 \%$ \\
\hline & Ingots & 535,140 & 7.82 & $99.48 \%$ & $22.91 \%$ \\
\hline & WP Liner & 601,360 & 7.83 & $99.41 \%$ & $19.53 \%$ \\
\hline & End & 633,780 & 8.05 & $99.26 \%$ & $17.94 \%$ \\
\hline md02_02 & \multicolumn{5}{|c|}{$\begin{array}{l}2 \text { stage run: Degrade glass and then expose ingots. Stage 1: high glass and drip rates, low Ingot and SS } \\
\text { rates. Stage 2: change to high stainless rate and low drip rate (causes a low pH in the second stage). }\end{array}$} \\
\hline \multicolumn{2}{|r|}{ Reactant Fully Degraded } & Time (years) & pH & $\%$ Gd Remaining & $\%$ U Remaining \\
\hline & Glass & 14,839 & 8.81 & $100.00 \%$ & $55.85 \%$ \\
\hline & Ingots & 16,721 & 7.02 & $100.00 \%$ & $55.79 \%$ \\
\hline & WP Liner & 44,545 & 5.32 & $99.59 \%$ & $55.68 \%$ \\
\hline & End & 634,170 & 7.90 & $99.54 \%$ & $54.03 \%$ \\
\hline md02_03 & \multicolumn{5}{|c|}{$\begin{array}{l}\text { Maximum volume of ingots that fit in a DOE can with a minimum ingot liner thickness }(1 \mathrm{~mm}) \text {. } \\
2 \text { stage run: Degrade ingots and then expose glass. Low glass rate, mean drip rate, high ingot and SS } \\
\text { rates. }\end{array}$} \\
\hline \multicolumn{2}{|r|}{ Reactant Fully Degraded } & Time (years) & pH & $\%$ Gd Remaining & $\%$ U Remaining \\
\hline & Ingots & 1,506 & 5.44 & $77.35 \%$ & $96.69 \%$ \\
\hline & WP Liner & 30,091 & 5.75 & $77.21 \%$ & $96.42 \%$ \\
\hline & Glass & 229,650 & 8.68 & $77.21 \%$ & $0.00 \%$ \\
\hline & End & 633,820 & 8.07 & $77.06 \%$ & $0.00 \%$ \\
\hline \multicolumn{6}{|l|}{ md02_06 } \\
\hline \multicolumn{2}{|r|}{ Reactant Fully Degraded } & Time (years) & pH & $\%$ Gd Remaining & $\%$ U Remaining \\
\hline \multicolumn{2}{|r|}{ WP Liner } & 60,134 & 5.85 & $100.00 \%$ & $99.97 \%$ \\
\hline \multicolumn{2}{|r|}{ Glass } & 248,180 & 8.67 & $100.00 \%$ & $29.17 \%$ \\
\hline \multicolumn{2}{|r|}{ Ingots } & 519,930 & 8.07 & $99.62 \%$ & $19.09 \%$ \\
\hline \multicolumn{2}{|r|}{ End } & 633,800 & 8.07 & $99.37 \%$ & $18.44 \%$ \\
\hline
\end{tabular}

The results of this illustrative table as well as most EQ6 runs show that in most of the cases more than $80 \%$ of the Gd will remain in the waste package, although the two-stage scenario exposing the MD ingots first and then the glass potentially loses more Gd.

Various computational assumptions were tested, in order to investigate how various sequences of degradation might proceed and affect the retention of gadolinium. Such geochemical sensitivity analyses investigating the formation $\mathrm{GdPO}_{4} \cdot \mathrm{H}_{2} \mathrm{O}$ and/or iron minerals identified a potential for severe, or complete, depletion of $\mathrm{Gd}$. These calculations are discussed next. 


\subsection{Impact of Suppression of $\mathrm{GdPO}_{4} \cdot \mathbf{1 0 H}_{2} \mathrm{O}$ Formation}

$\mathrm{GdPO}_{4} \cdot 10 \mathrm{H}_{2} \mathrm{O}$, is the most likely $\mathrm{Gd}$ mineral to form, and was artificially suppressed in two cases, to study the sensitivity of results to the formation of $\mathrm{GdPO}_{4} \cdot 10 \mathrm{H}_{2} \mathrm{O}$. The suppression of formation of a mineral is an option available in EQ6 software code. Although completely suppressing the formation of minerals most likely to form is extreme and unrealistic, this is useful method in investigating the sensitivity of Gd and U. Table 4.2 illustrates findings from sensitivity calculations performed.

Table 4.2 Cases Suppressing $\mathrm{GdPO}_{4} \cdot \mathbf{1 0 H}_{2} \mathrm{O}$ Formation

\begin{tabular}{|c|c|c|c|c|c|}
\hline $\begin{array}{l}\text { md02_03 } \\
\text { (base case) }\end{array}$ & \multicolumn{5}{|c|}{$\begin{array}{l}\text { Maximum volume of ingots that fit in a DOE can with a minimum ingot liner thickness ( } 1 \mathrm{~mm}) \text {. } \\
2 \text { stage run: Degrade ingots and then expose glass. Low glass rate, mean drip rate, high ingot and SS rates. }\end{array}$} \\
\hline \multicolumn{2}{|c|}{ Reactant Fully Degraded } & Time (years) & $\mathrm{pH}$ & $\%$ Gd Remaining & \% U Remaining \\
\hline & Ingots & 1,506 & 5.44 & $77.35 \%$ & $96.69 \%$ \\
\hline & WP Liner & 30,091 & 5.75 & $77.21 \%$ & $96.42 \%$ \\
\hline & Glass & 229,650 & 8.68 & $77.21 \%$ & $0.00 \%$ \\
\hline & End & 633,820 & 8.07 & $77.06 \%$ & $0.00 \%$ \\
\hline $\begin{array}{l}\text { md02_03 } \\
\text { Suppress } \\
\mathrm{GdPO}_{4} \cdot 10 \mathrm{H}_{2} \mathrm{O}\end{array}$ & \multicolumn{5}{|c|}{$\begin{array}{l}\text { Maximum volume of ingots that fit in a DOE can with a minimum ingot liner thickness }(1 \mathrm{~mm}) \text {. } \\
2 \text { stage run: Degrade ingots and then expose glass. Low glass rate, mean drip rate, high ingot and SS rates. }\end{array}$} \\
\hline \multicolumn{2}{|c|}{ Reactant Fully Degraded } & Time (years) & pH & $\%$ Gd Remaining & \% U Remaining \\
\hline & Ingots & 1,506 & 5.68 & $18.09 \%$ & $96.71 \%$ \\
\hline & WP Liner & 30,091 & 5.75 & $0.00 \%$ & $96.44 \%$ \\
\hline & Glass & 229,090 & 8.84 & $0.00 \%$ & $0.07 \%$ \\
\hline & End & 633,820 & 8.07 & $0.00 \%$ & $0.00 \%$ \\
\hline $\begin{array}{l}\text { md02_06 } \\
\text { (base case) }\end{array}$ & \multicolumn{5}{|c|}{$\begin{array}{l}\text { Maximum volume of ingots that fit in a DOE can with a minimum ingot liner thickness }(1 \mathrm{~mm}) \text {. } \\
\text { Ingots and glass degrade together, low glass rate, mean } \mathrm{SS} \text { and drip rates, low ingot rate. }\end{array}$} \\
\hline \multicolumn{2}{|c|}{ Reactant Fully Degraded } & Time (years) & $\mathrm{pH}$ & $\%$ Gd Remaining & $\%$ U Remaining \\
\hline & WP Liner & 60,134 & 5.85 & $100.00 \%$ & $99.97 \%$ \\
\hline & Glass & 248,180 & 8.67 & $100.00 \%$ & $29.17 \%$ \\
\hline & Ingots & 519,930 & 8.07 & $99.62 \%$ & $19.09 \%$ \\
\hline & End & 633,800 & 8.07 & $99.37 \%$ & $18.44 \%$ \\
\hline $\begin{array}{l}\text { md02_06 } \\
\text { Suppress } \\
\mathrm{GdPO}_{4} \cdot 10 \mathrm{H}_{2} \mathrm{O}\end{array}$ & \multicolumn{5}{|c|}{$\begin{array}{l}\text { Maximum volume of ingots that fit in a DOE can with a minimum ingot liner thickness }(1 \mathrm{~mm}) \text {. } \\
\text { Ingots and glass degrade together, low glass rate, mean SS and drip rates, low ingot rate. }\end{array}$} \\
\hline \multicolumn{2}{|c|}{ Reactant Fully Degraded } & Time (years) & pH & $\%$ Gd Remaining & \% U Remaining \\
\hline \multicolumn{2}{|r|}{ WP Liner } & 60,134 & 5.85 & $88.49 \%$ & $99.98 \%$ \\
\hline \multicolumn{2}{|r|}{ Glass } & 248,220 & 8.83 & $84.24 \%$ & $29.22 \%$ \\
\hline \multicolumn{2}{|r|}{ Ingots } & 519,930 & 8.07 & $83.37 \%$ & $18.98 \%$ \\
\hline \multicolumn{2}{|r|}{ End } & 633,820 & 8.07 & $83.12 \%$ & $18.33 \%$ \\
\hline
\end{tabular}

Because the formation of $\mathrm{GdPO}_{4} \cdot 10 \mathrm{H}_{2} \mathrm{O}$ was suppressed, the mineral $\mathrm{GdOHCO}_{3}$ forms instead of $\mathrm{GdPO}_{4} \cdot 10 \mathrm{H}_{2} \mathrm{O}$. The conservative two-stage case md02_03 retains $77 \%$ of the initial Gd content with the formation of $\mathrm{GdPO}_{4} \cdot 10 \mathrm{H}_{2} \mathrm{O}$. However, with $\mathrm{GdPO}_{4} \cdot 10 \mathrm{H}_{2} \mathrm{O}$ formation suppressed, all Gd is predicted to be lost (md02-03). This case demonstrates a strong sensitivity of Gd retention to $\mathrm{GdPO}_{4} \cdot 10 \mathrm{H}_{2} \mathrm{O}$ formation, but requires the unlikely event of the ingots degrading in the absence of the glass in addition to the complete suppression of $\mathrm{GdPO}_{4} \cdot 10 \mathrm{H}_{2} \mathrm{O}$ formation. Thermodynamic data indicate that $\mathrm{GdPO}_{4} \cdot 10 \mathrm{H}_{2} \mathrm{O}$ will form, and since it's formation is key to retaining $\mathrm{Gd}$, retention of $\mathrm{Gd}$ should be further investigated. This can be accomplished by a detailed analysis of the experiments on which the data is based to show applicability to the current situation, by further analysis and/or experiments. 
In another case (md02_06), even with the $\mathrm{GdPO}_{4} \cdot 10 \mathrm{H}_{2} \mathrm{O}$ formation suppressed, $83 \%$ of the Gd remains, as compared to the $99 \%$ that remained in the case where $\mathrm{GdPO}_{4} \cdot 10 \mathrm{H}_{2} \mathrm{O}$ was allowed to form, since $\mathrm{GdOHCO}_{3}$ is less likely to form than $\mathrm{GdPO}_{4} \cdot 10 \mathrm{H}_{2} \mathrm{O}$. The suppression of $\mathrm{GdPO}_{4} \cdot 10 \mathrm{H}_{2} \mathrm{O}$ formation does not affect the percentage of $\mathrm{U}$ remaining in either case. ${ }^{9}$

\subsection{Suppressing the Formation of Iron Minerals to Control Ionic Strength}

Hematite and goethite are predicted to form in the waste package under normal running of EQ6. At early times in the EQ3/6 runs when the stainless steels are degrading, the $\mathrm{pH}$ is low and the ionic strength is high due to the presence of $\mathrm{Ni}^{++}, \mathrm{Cr}_{2} \mathrm{O}_{7}^{--}$, and $\mathrm{HCrO}_{4}^{-}$ions in solution. If the most stable iron oxides (hematite and goethite) are suppressed in the EQ3/6 runs, then the more soluble $\mathrm{Fe}(\mathrm{OH})_{3}$ forms.

Allowing $\mathrm{Fe}(\mathrm{OH})_{3}$ to form causes the $\mathrm{pH}$ to increase closer to neutral and the ionic strength to decrease to less than 1.0. For the purpose of investigating the sensitivity, the formation of these minerals was suppressed to determine if there is any effect on the results. Table 4.3 illustrates the results of suppressing the formation of various iron minerals.

The case md02_03 is one of the few cases with an ionic strength greater than 1.0, therefore this case was used to see the effect of suppressing the formation of iron minerals. The first case, fe02_03, suppresses the formation of goethite, hematite, and andradite for the first thousand years, which is the time period where the ionic strength was high in case md02_03. The results of case fe02_03 show that the time span with an ionic strength of more than 1.0 is reduced from 470 years to 300 years, although the actual ionic strength peak for this case is higher. The second case, fs02_03, suppresses the formation of goethite, hematite, and andradite, like case fe02_03, and suppresses the formation of $\mathrm{GdPO}_{4} \cdot 10 \mathrm{H}_{2} \mathrm{O}$. The ionic strength did not increase above 1.0 for this case. The third case, he02_03, suppresses the formation only for hematite. This case has a higher ionic strength peak than the original case. Case al02_03 suppressed the aluminum minerals diaspore and gibbsite to determine the sensitivity of the model on aluminum mineral production. Again, the effect of suppressing $\mathrm{GdPO}_{4} \cdot 10 \mathrm{H}_{2} \mathrm{O}$ becomes evident.

The percentage of $\mathrm{Gd}$ remaining for these cases varies considerably. When the formation of the three iron minerals is suppressed in case fe02_03, the pH is lower from 1,000 to 3,000 years, therefore more of the $\mathrm{Gd}$ is washed out of the waste package during that time. The case that also suppresses $\mathrm{GdPO}_{4} \cdot 10 \mathrm{H}_{2} \mathrm{O}$ formation (case fs02_03) loses all the $\mathrm{Gd}$, but it is unlikely that $\mathrm{GdPO}_{4} \cdot 10 \mathrm{H}_{2} \mathrm{O}$ will not form. ${ }^{9}$ Case he02_03 retains more $\mathrm{Gd}$ because the $\mathrm{pH}$ is slightly higher from 1,000 to 1,200 years, as the ingots finish degrading, and that higher $\mathrm{pH}$ allows more $\mathrm{GdPO}_{4} \cdot 10 \mathrm{H}_{2} \mathrm{O}$ to form. Results from the cases where hematite (case he02_03) or the aluminum minerals, diaspore and gibbsite, (case al02_03) are suppressed indicate only a slight change in Gd retention from that of the base case (case md02_03). The amount of $U$ that remains in the waste package is unaffected by the suppression of any of the minerals considered in Table 4.3. 
Table 4.3 Cases Suppressing the Formation of Various Minerals

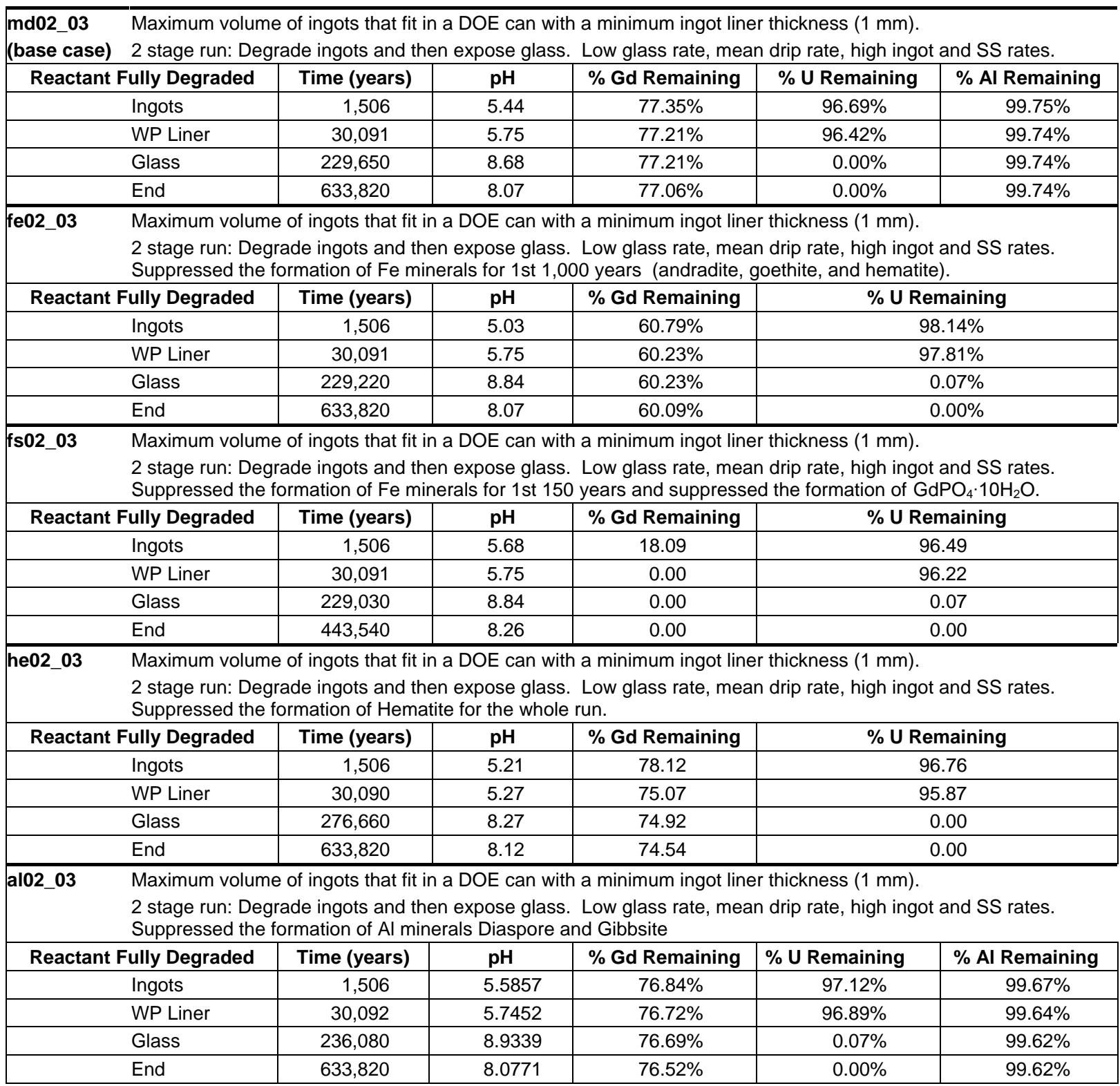

\subsection{Geochemistry Analysis Conclusions}

Most of the cases show that more than $80 \%$ of the initial Gd content will remain in the waste package, although the two-stage scenario exposing the MD ingots first and then the glass potentially loses more Gd. This case uses unrealistic input conditions, i.e. requires the unlikely event of the ingots degrading while isolated from the DHLW glass, in addition to the complete suppression of $\mathrm{GdPO}_{4} \cdot 10 \mathrm{H}_{2} \mathrm{O}$ formation. Since thermodynamic data indicate that $\mathrm{GdPO}_{4} \cdot 10 \mathrm{H}_{2} \mathrm{O}$ will form, and because its formation is key to retaining $\mathrm{Gd}$, retention of $\mathrm{Gd}$ should be further demonstrated. This can be accomplished by further analysis of the experiments on which the data is based to show applicability to the current situation and/or experiments. 


\subsection{SHIELDING ANALYSIS}

\subsection{Computer Software}

The Monte Carlo particle transport code, MCNP, Version 4B2LV (CRWMS M\&O 1998f), is used to calculate average dose rates at the external surfaces of the waste package. The information regarding the code and its use for the shielding analysis is documented in BSC (2001b).

The Monte Carlo method for solving the integral radiation transport equation, which is implemented in the MCNP computer program, is used to calculate radiation dose rates for the waste packages. MCNP uses continuous-energy cross sections processed from the evaluated nuclear data files ENDF/B-V. ${ }^{13}$ These cross-section libraries are part of the qualified MCNP code. The flux averaged over a surface tally is specified in calculations and the neutron and gamma flux-to-dose rate conversion factors ${ }^{14}$ are applied to obtain surface dose rates.

\subsection{Calculations \& Results}

Reference 5 specifies the design criteria for the maximum rate of 1,450 rem/hr on all external surface of the WP. The geometric representation of the waste package used in MCNP calculations is shown in Figure 5.1. The waste package contains two different radiation sources, which are volumetric sources uniformly distributed inside the cavity of the DOE SNF canister and the glass volume, respectively. A conservative approach is used, in which lower material densities for the SRS DHLW glass and the MD ingots are employed.

In the calculation, the external surfaces of the waste package are divided in segments and the dose rate is averaged over each segment to evaluate the spatial distribution of the dose rate. Figure 5.2 and Figure 5.3 show the segments of the radial and axial segments used in the dose-rate calculations. The radial surface, between the bottom and top planes of DHLW glass, is equally divided into five segments, each of which is $47.886-\mathrm{cm}$ high. The first radial segment (Segment 1), 64.57-cm high, corresponds to the empty portion of the DHLW canister, which is between the top of the waste package cavity and the top of the DHLW glass. The waste package top and bottom axial surfaces are divided into two radial segments of $0-30 \mathrm{~cm}$ (Segment 7) and 30-101.5 cm (Segment 8). For this waste package, the DOE canister is positioned in the center of the waste package and gamma source intensity of the MD ingots is twenty times the gamma source intensity of each individual SRS DHLW glass canister. Because the DHLW glass canisters are positioned near the disposal container, they attenuate the radiation emitted by the MD SNF and mostly determine the dose rates on the angular segments adjacent to them (Segments B). However, due to their higher source intensity, the MD ingots contribute to the dose rates averaged over Segments A. Therefore, an angular dependence of the waste package radial dose is expected and the radial surface is divided into ten equal angular segments, as shown in Figure 5.3. 
Side View

\section{Top View}

Extended Outer Shell Lid Base

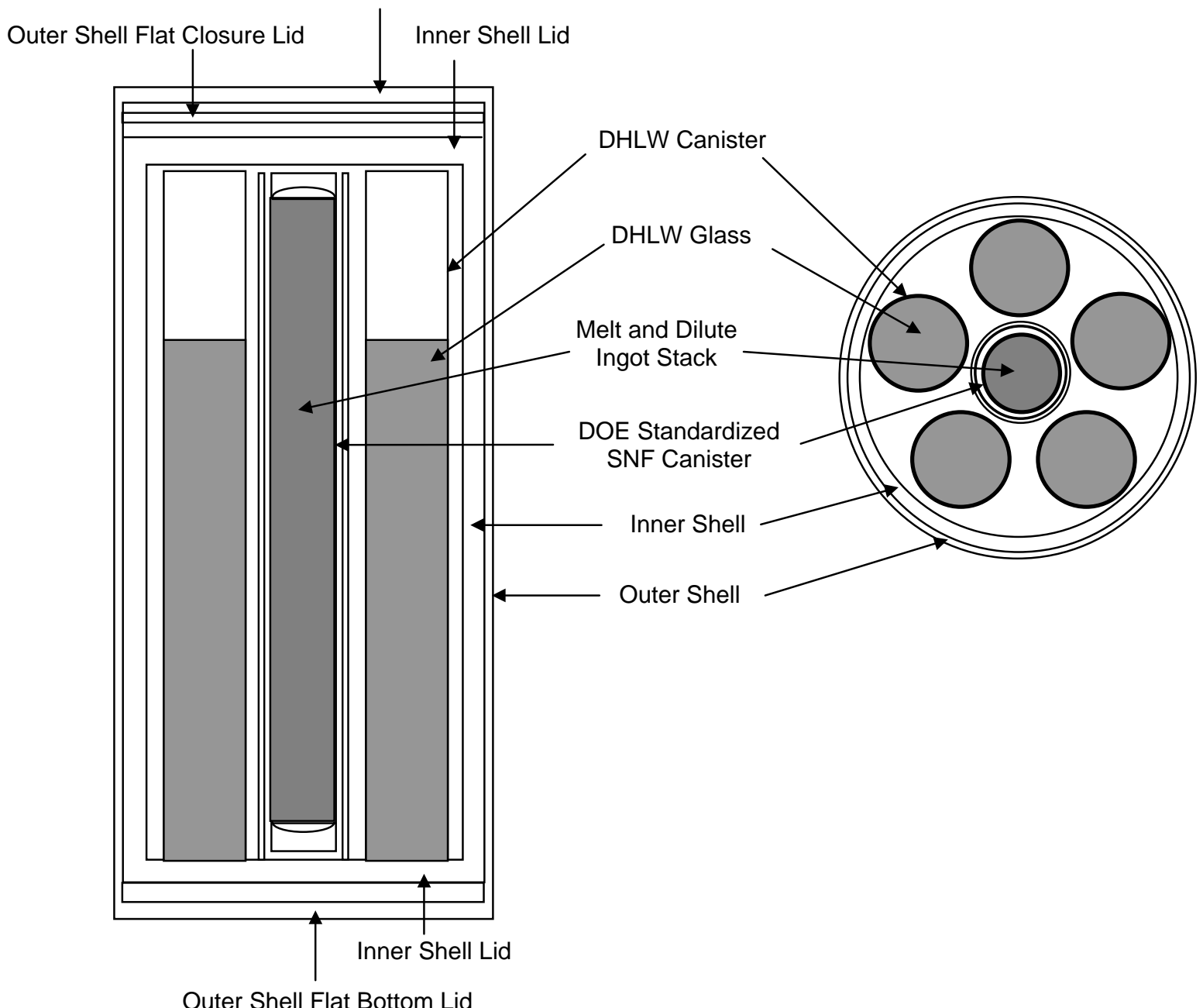

Figure 5.1 Vertical and Horizontal Cross Sections of MCNP Geometry Representation

Table 5.1 and Table 5.2 provide radial and axial dose rates on the outer surface of the waste package containing the five SRS DHLW glass canisters and the DOE SNF canister. The neutron source has an insignificant contribution to the total dose and the gamma dose dominates the total dose. 


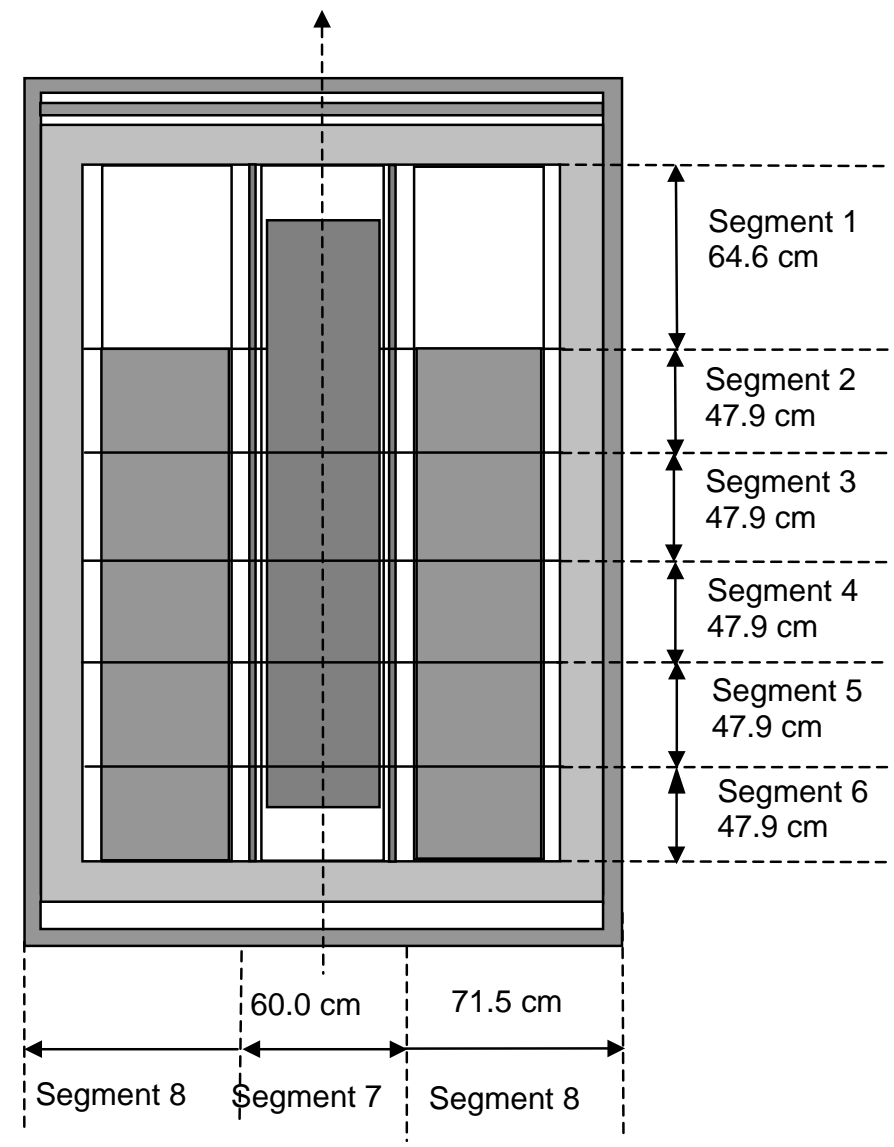

Figure 5.2 Surfaces and Segments (axial and radial) Used for Dose Rate Calculations

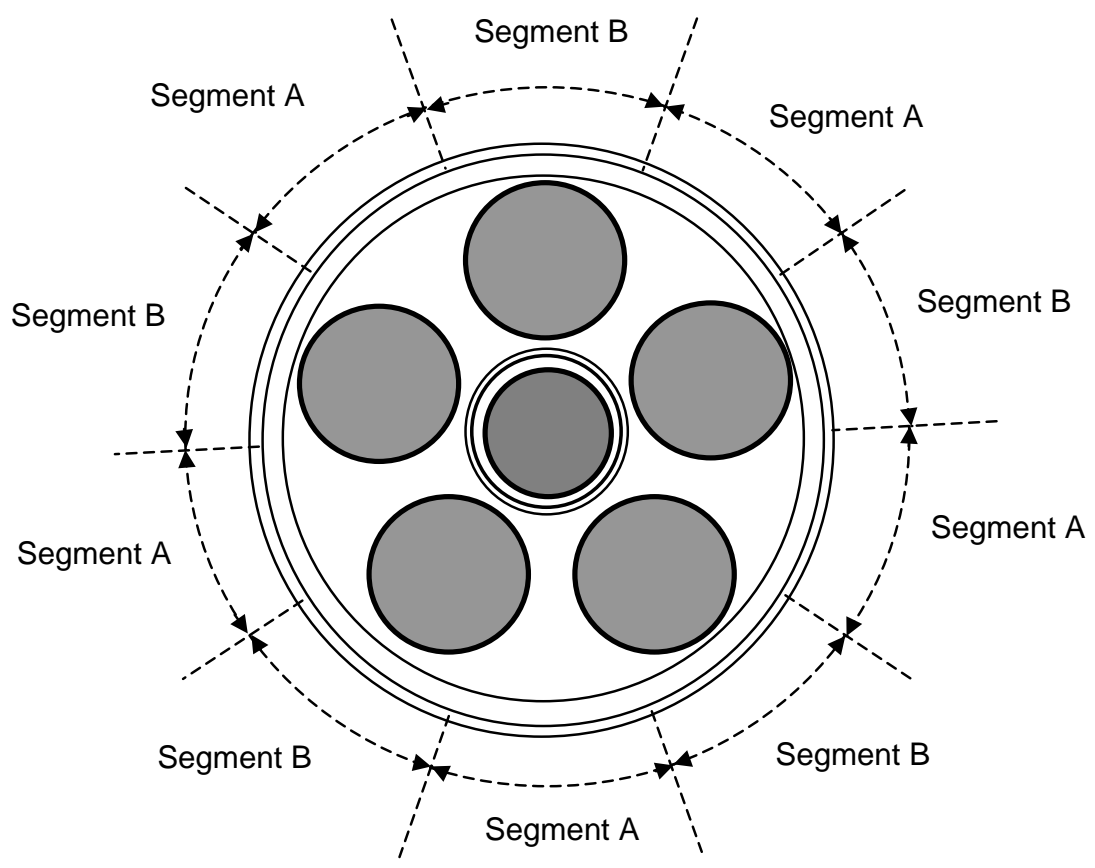

Figure 5.3 Angular Segments of the WP Outer Radial Surface Used in Dose Rate Calculations 
Table 5.1 Dose Rates Averaged over Axial and Radial Segments of the WP Outer-Radial and Axial Surfaces ${ }^{5}$

\begin{tabular}{|l|c|c|c|}
\hline Location & $\begin{array}{c}\text { Gamma Dose Rate } \\
(\mathbf{r e m} / \mathbf{h})\end{array}$ & $\begin{array}{c}\text { Neutron Dose Rate } \\
(\mathbf{r e m} / \mathbf{h})\end{array}$ & $\begin{array}{c}\text { Total Dose Rate } \\
(\mathbf{r e m} / \mathbf{h})\end{array}$ \\
\hline Radial surface: Segment 1 & 85.47 & 0.14 & 85.61 \\
\hline Radial surface: Segment 2 & 133.53 & 0.14 & 133.67 \\
\hline Radial surface: Segment 3 & 144.49 & 0.15 & 144.64 \\
\hline Radial surface: Segment 4 & 143.34 & 0.15 & 143.49 \\
\hline Radial surface: Segment 5 & 136.42 & 0.14 & 136.57 \\
\hline Radial surface: Segment 6 & 105.20 & 0.11 & 105.31 \\
\hline Bottom surface: Segment 7 & 47.50 & 0.22 & 47.71 \\
\hline Bottom surface: Segment 8 & 13.76 & 0.08 & 13.84 \\
\hline Top surface: Segment 7 & 27.30 & 0.15 & 27.45 \\
\hline Top surface: Segment 8 & 4.82 & 0.08 & 4.89 \\
\hline
\end{tabular}

NOTE: The dose rates listed in this table are the upper limits of the 95 percent confidence intervals of the Monte Carlo dose rate calculations.

The radial surface dose rates have an angular dependence, as shown in Table 5.2. The dose rate averaged over Segment A is approximately twice as much as the dose rate averaged over Segment B.

Table 5.2 Dose Rates Averaged Over Angular Segments of the WP Outer-Radial Surface

\begin{tabular}{|l|c|c|c|c|c|c|}
\hline & \multicolumn{3}{|c|}{ Angular Segment A } & \multicolumn{3}{c|}{ Angular Segment B } \\
\cline { 2 - 7 } $\begin{array}{l}\text { Axial } \\
\text { Location }\end{array}$ & $\begin{array}{c}\text { Gamma } \\
\text { Dose Rate } \\
(\mathbf{r e m} / \mathbf{h})\end{array}$ & $\begin{array}{c}\text { Neutron } \\
\text { Dose Rate } \\
(\mathbf{r e m} / \mathbf{h})\end{array}$ & $\begin{array}{c}\text { Total Dose } \\
\text { Rate } \\
(\mathbf{r e m} / \mathbf{h})\end{array}$ & $\begin{array}{c}\text { Gamma } \\
\text { Dose Rate } \\
(\mathbf{r e m} / \mathbf{h})\end{array}$ & $\begin{array}{c}\text { Neutron } \\
\text { Dose Rate } \\
(\mathbf{r e m} / \mathbf{h})\end{array}$ & $\begin{array}{c}\text { Total Dose } \\
\text { Rate } \\
(\mathbf{r e m} / \mathbf{h})\end{array}$ \\
\hline Segment 1 & 104.33 & 0.16 & 104.49 & 74.42 & 0.14 & 74.56 \\
\hline Segment 2 & 182.66 & 0.19 & 182.85 & 98.68 & 0.11 & 98.79 \\
\hline Segment 3 & 199.69 & 0.20 & 199.89 & 103.21 & 0.11 & 103.32 \\
\hline Segment 4 & 199.13 & 0.20 & 199.33 & 101.38 & 0.10 & 101.48 \\
\hline Segment 5 & 185.52 & 0.20 & 185.72 & 100.46 & 0.11 & 100.57 \\
\hline Segment 6 & 132.09 & 0.14 & 132.23 & 92.80 & 0.08 & 92.88 \\
\hline
\end{tabular}

NOTE: The dose rates listed in this table are the upper limits of the 95 percent confidence intervals of the Monte Carlo dose rate calculations.

\subsection{Shielding Analysis Summary}

The maximum dose rate at the external surfaces of the waste package occurs on the radial surface and is $199.89 \mathrm{rem} / \mathrm{h}$. The radial dose rate shows an angular distribution, with dose rates on Segments A being approximately twice as much as those on Segments B. The dose rates on the bottom and top surfaces of the waste package are about one-third and about one-fifth, respectively, of the maximum dose rate on the outer radial surface. The design criterion specifies that the maximum dose rate at all external surfaces of the waste package is $1,450 \mathrm{rem} / \mathrm{h} .{ }^{5}$ The dose rates in rem $/ \mathrm{h}$ and $\mathrm{rad} / \mathrm{h}$ are practically the same due to the insignificant contribution of the neutron dose rate to the total dose rate. 
Radiation produces radiolytic species (e.g., hydrogen peroxide and nitric acid) that may enhance the corrosion of the waste package components. A study that has evaluated the effect of radiation on the corrosion of the material used for the fabrication of waste packages in the environments expected at Yucca Mountain ${ }^{15}$ showed that a dose rate of $10^{4} \mathrm{rad} / \mathrm{h}$ is required before any influence of radiation is observed on copper/nickel alloys. Since the calculated dose rate at the external surface of the MD waste package is approximately $200 \mathrm{rem} / \mathrm{h}$, it is expected that no observable effect on the corrosion of waste package materials will be present. 


\subsection{REFERENCES}

1 DOE Spent Nuclear Fuel Grouping in Support of Criticality, DBE, TSPA-LA. DOE/SNF/REP-046, Rev. 0. Washington, D.C.: U.S. Department of Energy, Office of Nuclear Material and Spent Fuel. TIC: 248046 (2000).

2 Statement of Work for DOE - Office of Civilian Waste Management, Technical Assistance on MeltDilute Criticality and Shielding Analyses. Revision 2. Las Vegas, Nevada: Bechtel SAIC Company, LLC. ACC: MOL.20010619.0626 (2001).

3 Evaluation of Codisposal Viability for Melt and Dilute DOE-Owned Fuel. TDR-EDC-NU-000006, Rev. 00D. Las Vegas, Nevada: Bechtel SAIC Company (July 2001).

4 Disposal Criticality Analysis Methodology Topical Report. YMP/TR-004Q, Rev. 01. Las Vegas, Nevada: Yucca Mountain Site Characterization Office. ACC: MOL.20001214.0001 (2000).

5 Dose Rate Calculation for the Codisposal Waste Package of HLW Glass and the Melt and Dilute Al SNF. CAL-DDC-NU-000004 REV 00. Las Vegas, Nevada: Bechtel SAIC Company. URN-xxx (2001).

6 Evaluation of Codisposal Viability for Aluminum-Clad DOE-Owned Spent Fuel: Phase II. Degraded Codisposal Waste package Internal Criticality. BBA000000-01717-00017 Rev 01. Las Vegas, Nevade: CRWMS M\&O. ACC: MOL.19981014.0038 (1998).

7 Software Code: MCNP. 4B2LV. HP. 30033 V4B2LV (1998).

8 Intact and Degraded Mode Criticality Calculations for the Codisposal of Melt and Dilute Ingots in a Waste Package. CAL-EDC-NU-000006 REV 00. Las Vegas, Nevada: Bechtel SAIC Company. URN-0922 (2001).

9 EQ6 Calculation for Chemical Degradation of Melt and Dilute Waste Packages. CAL-EDC-MD000012 REV 00. Las Vegas, Nevada: Bechtel SAIC Company. MOL.20010719.0064 (2001).

10 DSNF and Other Waste Form Degradation Abstraction. ANL-WIS-MD-000004 REV 01 ICN 01. Las Vegas, Nevada: CRWMS M\&O. ACC: MOL.20010316.0002 (2000).

11 Software Code: EQ3/6. V7.2b. LLNL: UCRL-MA-110662 (1998).

12 Software Code: EQ6, Version 7.2bLV. V7.2bLV. 10075-7.2bLV-00 (1999).

13 Briesmeister, J.F., ed. MCNP-A General Monte Carlo N-Particle Transport Code. LA-12625-M, Version 4B. Los Alamos, New Mexico: Los Alamos National Laboratory. ACC: MOL.19980624.0328 (1997).

14 ANSI/ANS-6.1.1-1977. Neutron and Gamma-Ray Flux-to-Dose-Rate Factors. La Grange Park, Illinois: American Nuclear Society. TIC: 239401 (1977).

15 Shoesmith, D.W., and King, F. "The Effects of Gamma Radiation on the Corrosion of Candidate Materials for the Fabrication of Nuclear Waste Packages." AECL - 11999. Pinawa, Manitoba, Canada: Atomic Energy of Canada Limited (1998). 

WESTINGHOUSE SAVANNAH RIVER CO. REPORT WSRC-TR-2001-00421

\section{DISTRIBUTION}

\section{SAVANNAH RIVER SITE}

W. A. Condon, 703-F

C. R. Wolfe, 773-A

N. C. Iyer, 773-41A

H. M. Brooks, 707-C

W. F. Swift, 707-C

B. R. Hess, 707-C

W. S. Large, 707-C

B. A. Eberhard, 707-C

R. L. Sindelar, 773-41A

H. B. Peacock, Jr., 773-A

D. W. Vinson, 773-41A

T. M. Adams, 773-41A

R. W. Ponik, 703-F

Site Records 